\title{
Can adulteration of urine samples mask cannabis detection by GC-MS?
}

\author{
Reda M. Elsayed ${ }^{1}$, Mohammed A. Abdel Ati ${ }^{1}$, Khaled M. Mohamed ${ }^{2}$ and Maha A. Hilal ${ }^{1}$ \\ ${ }^{1}$ Forensic Medicine and Clinical Toxicology Department, Faculty of Medicine, Sohag University, Sohag, Egypt. \\ ${ }^{2}$ College of Forensic Sciences-Naif Arab University for Security Sciences,Ryadh ,Saudi Arabia.
}

\begin{abstract}
Background: Together with coffee and tobacco, Cannabis is the most commonly used psychoactive drug worldwide, and it is the single most popular illegal drug. Recent studies have demonstrated increase in the prevalence of the use of cannabis. A limitation inherent in all urine drug testing is the possibility of sample adulteration or substitution.
\end{abstract}

Aim of study: To detect qualitative and quantitative effects of five adulterants on positive urine samples for tetrahydrocannabinol carboxylic acid (THC-COOH).

Material and Method(s): This analytical study was conducted in Clinical Toxicology Laboratory in Sohag University Hospitals. Urine samples positive to cannabis adulterated with vinegar, drano liquid hand soap, visine eye drops and bleach were tested by immunoassay (RIA) then confirmed and quantified by GC-MS.

Results: Urine samples adulterated with vinegar, drano liquid hand soap, visine and bleach generated false negative results by immunoassay testing. GC-MS confirmation showed that addition of vinegar, bleach, visine, drano and liquid hand soap decrease THC-COOH significantly with increased concentration.

Conclusion: Some adulterants make it easy to produce false negative results on RIA testing for cannabis and GC-MS is important to overcome adulteration methods in urine analysis.

Key words

Drug abuse, cannabis detection, Urine adulteration, GC-MS confirmation

\section{Introduction}

$\mathrm{S}$ ubstance abuse in Egypt is a serious public health threat. Recent studies have demonstrated increase in the prevalence of the use of cannabis and tramadol (Saleh, 2015).

Together with coffee and tobacco, Cannabis is the most commonly used psychoactive drug worldwide, and it is the single most popular illegal drug. Worldwide over 160 million people are using Cannabis regularly and these numbers are still rising (Grotenhermen and Russo, 2002)

$\Delta 9$-tetrahydrocannabinol $(\triangle 9$-THC $) \quad$ and cannabidiol (CBD) are the most important constituents of the plant cannabinoids. $\triangle 9$-THC is thought to be the principal intoxicant constituent of cannabis. (Radwan et al., 2008).

Cannabis can impair driving skills and people driving under the influence of cannabis are 20-30\% more likely to be involved in a car accident (Hall and Degenhardt, 2015).

The global burden of disease attributable to cannabis use disorder, expressed in disability-adjusted life years (DALYs) as 646480 DALYs in 2016. One DALY represents one year of life lost either due to premature mortality or due to living with disability. Driving under the influence of cannabis increases the risk of accidents and is therefore a public health threat (Kassebaum et al., 2016).
According to Hamdi et al., (2016) Cannabis was the commonest substances of abuse in Egypt, in total, $77 \%$ of the substance users were using Cannabis.

According to study conducted in Zagazig city on a sample of 130 commercial drivers, $57.7 \%$ among the participants tested positive for substance abuse and the most common abused substance was cannabis which represented $80 \%$ of the positive participants (Hammam et al., 2018).

A limitation inherent in all urine drug testing is the possibility of sample adulteration or substitution (Jaffee et al., 2007).

The use of adulterant agents can cause false negative results in drug tests by either change $\mathrm{PH}$ or decrease concentration by dilution effect which leads to interfering with the screening test procedure and/or destroying the drugs present in the urine sample (Yee et al., 2014).

\section{Aim of the Work}

To detect qualitative and quantitative effects of five adulterants on positive urine samples for cannabis. 


\section{Materials and Methods}

This analytical study was conducted in Sohag Clinical Toxicology Laboratory from January 2020 to October 2020.

Acceptable samples (inclusion criteria): the samples were from 10-100 ml urine in volume, voided in a clean dry labeled container without preservative. The samples were tested by immunoassay for tetrahydrocannabinol carboxylic acid (THC-COOH), positive samples only were included.

Five Types of adulterants were used.

- Vinegar, bleach, visine eye drops and liquid drano at 3 concentrations $10 \%, 20 \%$ and $40 \%$.

- $\quad$ Liquid hand soap at 3 conc. 5\%, $10 \%$ and $20 \%$.

These adulterants levels were selected to obtain an accurate representation of real-world samples adulteration as it would easy to be brought in a small container and added to the urine samples.

Number of samples included:

There were 45 adulterated urine samples, one blank urine sample and one sample diluted with water $40 \%$ to exclude dilution effect (total 47 samples).

- To prepare adulterated samples, $1 \mathrm{~mL}$ aliquots were obtained from the urine samples for each drug (adulterant or agent). $1 \mathrm{ml}$ of the unadulterated urine sample was used to determine the initial concentration of the drug by GC-MS. The total volume of the adulterated samples was maintained at $1 \mathrm{ml}$. The amounts of liquid adulterants were added to the urine sample to reach the $1 \mathrm{ml}$ limit. The $10 \% \mathrm{v} / \mathrm{v}$ sample had 900 $\mu \mathrm{L}$ of urine and $100 \mu \mathrm{L}$ of adulterant. This process was followed for the remaining concentrations: 20 $\% \mathrm{v} / \mathrm{v}(800: 200) 40 \% \mathrm{v} / \mathrm{v}(600: 400)$ and 5\% v/v (950:50).

Screening of THC-COOH in urine samples by immunoassay:

Apparatus: Radio immunoassay apparatus using drug analyzer: (CDx90), Thermo-fisher Scientific co. supplier AMG Company. Fully automated random access analyzer, dedicated drug testing system (photometric). Its serial number 7218-0150 present in Sohag Clinical Toxicology Lab.

i- Principle of procedure:

The DRI Cannabinoid assay is a homogenous enzyme immunoassay with liquid ready to use reagents. The assay uses a specific antibody which can detect most Cannabinoid and their metabolites as (THC-COOH) in urine. The assay is based on the competition of enzyme glucose -6- phosphate dehydrogenase (G6PDH) labeled drug and the free drug in the urine sample for the fixed amount of antibody binding sites. In the absence of the free drug in the sample, the enzyme labeled drug is bound by the specific antibody and enzyme activity is inhibited. This phenomenon creates a relationship between drug concentration in urine and enzyme activity. The enzyme (G6PDH) activity is determined at 340nm spectrophotometrically by its ability to convert of NAD to NADH (Rainey and Baird, 2012). ii- Calibration: Figure (A)

1. For construction of the calibration curve (Linear Mode) we used the following calibrators:

- DRI Negative Urine Calibrator.

- DRI THC 50 ng/mL Calibrator.

2. For qualitative analysis we used the $50 \mathrm{ng} / \mathrm{ml}$ calibrator as a cutoff level to distinguish "positive" and "negative" specimens.

3. LQC: $40 \mathrm{ng} / \mathrm{ml}$ control negative results

HQC: $75 \mathrm{ng} / \mathrm{ml}$ control positive results.

Each conc. of each adulterant was added separately to urine sample and the samples were tested by immunoassay where cut off for THC detection was $50 \mathrm{ng} / \mathrm{ml}$ above it considered positive and below it considered negative and finally the samples were confirmed by GC-MS.

Confirmation and quantiatication of THC-COOH in urine samples by GC-MS:

Apparatus: An Agilent GC-MS-5977A MSD. (USA) with an Agilent auto-sampler was used for specimen analysis. The GC was equipped with Agilent HP-5MS (5\%-Phenyl-methylpolysiloxane) capillary column (30 $\mathrm{m} \times 250 \mu \mathrm{m} \times 0.25 \mu \mathrm{m}$ film thickness) present in faculty of science-Al Azhar University.

i- Calibrators and quality controls

i.1- Calibrators:

A stock solution of THC-COOH and delta 9THC-COOH at concentration of $100 \mu \mathrm{g} / \mathrm{mL}$ were prepared in methanol and kept stored at $-20^{\circ} \mathrm{C}$. Intermediate stock solution of $\mathrm{THC}-\mathrm{COOH}$ at concentration of $10 \mu \mathrm{g} / \mathrm{mL}$ was prepared by diluting (1:10) of THC-COOH stock standard $100 \mu \mathrm{g} / \mathrm{mL}$ in methanol. Working calibrators $(10,25,100,500$ and $1000 \mathrm{ng} / \mathrm{mL}$ ) of THC-COOH were made by a serial dilution of the intermediate solution with drug free human urine.

i.2- Controls:

One negative urine control was tested with every batch. The negative control was prepared using certified blank urine.

Two positive urine controls were tested with every batch. The positive controls were prepared using certified blank urine in the same way as sample preparation.

ii- Extraction procedure

1. $50 \mu \mathrm{L}$ of delta 9-THC-COOH (IS) at concentration of $5 \mu \mathrm{g} / \mathrm{mL}$ was added to $0.5 \mathrm{~mL}$ of urine samples in labeled tubes followed by adding $50 \mu \mathrm{L}$ of $10 \mathrm{~N}$ $\mathrm{NaOH}$ and shaked well by vortex for $10 \mathrm{sec}$.

2. The tubes incubated for a minimum of 20 minutes at $60^{\circ} \mathrm{C}$.

3. After cooling, $50 \mu \mathrm{l}$ acetic acid and $4 \mathrm{~mL}$ of 9:1 v/v hexane, ethyl acetate was added to each tube.

4. The tubes were capped and placed on a rotary mixer for 30 minutes.

5. The tubes were centrifuged for 5 minutes at 3200 rpm to achieve separation.

6. The top layer was transferred (extraction solvent) to clean, labeled cap tubes containing $0.5 \mathrm{~mL}$ of $1 \mathrm{~N}$ $\mathrm{NaOH}$

7. The tubes capped and placed on a rotary mixer for 20 minutes. 
8. Then the tubes were centrifuged for 5 minutes at $3200 \mathrm{rpm}$ to achieve separation.

9. The top solvent layer removed using vacuum pump, to the aqueous layers, $0.5 \mathrm{ml}$ of $4 \mathrm{~N} \mathrm{HCl}$ and $2 \mathrm{~mL}$ of 9:1 v/v hexane: ethyl acetate were added to each tube and shaked well by the vortex for $1 \mathrm{~min}$.

10. The tubes then centrifuged for 5 minutes at 3200 rpm.

11. The organic layer transferred in to labeled glass tubes and evaporated to dryness

iii- Derivatization

The residue samples were dissolved in $50 \mu \mathrm{L}$ of BSTFA (N,O-Bis (trimethylsilyl) trifluoroacetamide). Tubes were capped, mixed and incubated for $30 \mathrm{~min}$ at $70{ }^{\circ} \mathrm{C}$ in heater block. Samples were removed from heater block, allowed to cool at room temperature, and evaporated to dryness under nitrogen at $50{ }^{\circ} \mathrm{C}$. Samples were reconstituted with $50 \mu \mathrm{L}$ ethyl acetate and transferred to GC vial insert prior to GC-EI /MS analysis.

iv- GC/MS condition

Helium was used as the carrier gas at a flow rate of 1 $\mathrm{ml} / \mathrm{min}$. The injection volume was $2.0 \mu \mathrm{L}$ and injections were made in splitless mode. The injector port and interface were maintained at $280{ }^{\circ} \mathrm{C}$, and the detector at $225{ }^{0} \mathrm{C}$. The column temperature was maintained at $150{ }^{0} \mathrm{C}$ for 1 minute with a ramp of $20^{\circ} \mathrm{C} / \mathrm{min}$ to $310{ }^{0} \mathrm{C}$ and held for $3 \mathrm{~min}$. The ionizing energy was $70 \mathrm{eV}$. The total run time was $12 \mathrm{~min}$.

Electron Ionization (EI) mode was used and data were collected using single ion monitoring (SIM).

The principal ions at $\mathrm{m} / \mathrm{z} 371.473$, and 488 were used for THC-COO-(TMS) $)_{2}$; and m/z 380.479, and 497 were used for delta 9-THC-COO-(TMS) $)_{2}$, these ions were for quantification.

Data analysis was performed using the Agilent GC-MS software.

\section{Results}

Immunoassay screening for THC-COOH:

1. The parent sample concentration was $97 \mathrm{ng} / \mathrm{ml}$. (as the method of detection considered semiquantitative not only screening).

2. Addition of vinegar at high concentration $40 \%$ was able to successfully masking positive response of THC-COOH in tested urine samples. While moderate concentration (20\%) and low concentration (10\%) cannot affect THC-COOH detection in urine samples as shown in table (1) and figure (1).

3. On other hand addition of bleach, drano whatever their concentration were able to mask THC-COOH detection by immunoassay. For visine it was effective for decreasing the response rate for THC$\mathrm{COOH}$ using immunoassay method at high conc. $40 \%$ and $20 \%$ while $10 \%$ had no effect on THC$\mathrm{COOH}$ result as shown in table (1) and figure (1).

4. Unforturely, addition of liquid hand soap by any concentration even low concentration up to 5\% masked THC-COOH detection by immunoassay giving false negative results.as shown in table (2) GC-MS:

Detection and quantification of THC-COOH by

The parent positive sample concentration: 89ng/ml figure (5)
- Limit of detection (LOD): $0.875 \mathrm{ng} / \mathrm{ml}$

- Limit of quantification (LOQ): $1.75 \mathrm{ng} / \mathrm{ml}$

1. Effect of vinegar on THC-COOH detection \& quantification by GC-MS

Addition of vinegar in concentration 40\% leading to decrease in concentration of THC-COOH to more or less half of the actual concentration (43.3 $\mathrm{ng} / \mathrm{ml})$.

- While addition of $20 \%$ vinegar decrease THCCOOH concentration to $(65.2 \mathrm{ng} / \mathrm{ml})$

- Finally $10 \%$ has the least effect as there is minimal decrease from actual concentration $(79.4 \mathrm{ng} / \mathrm{ml})$ as shown in table (3) and figures (6, 7 \& 8).

2. Effect of bleach on THC-COOH detection \& quantification by GC-MS

Addition of bleach in concentration $40 \%$ decreased THC-COOH concentration to $(48.6 \mathrm{ng} / \mathrm{ml})$.

- While addition of $20 \%$ bleach decreased THC$\mathrm{COOH}$ concentration to $(71.3 \mathrm{ng} / \mathrm{ml})$

- Finally $10 \%$ bleach has the least effect as there is minimal decrease from actual concentration (80.2ng/ml) as shown in table (3) and Figures (9, 10 \& 11).

3. Effect of visine on THC-COOH detection \& quantification by GC-MS

- Addition of visine in concentration $40 \%$ decreased THC-COOH concentration to (42 ng/ml).

- While addition of $20 \%$ visine decreased THC$\mathrm{COOH}$ concentration to $(63.6 \mathrm{ng} / \mathrm{ml})$.

- Finally $10 \%$ has the least effect as there is minimal decrease from actual concentration $(77.3 \mathrm{ng} / \mathrm{ml})$ as shown in table (3) and figures (12, 13 \& 14).

4. Effect of drano on THC-COOH detection \& quantification by GC-MS

- Addition of drano in concentration $40 \%$ leading to decreased in concentration of THC-COOH to (53.4 $\mathrm{ng} / \mathrm{ml})$.

- While addition of $20 \%$ drano cause decreased in THC-COOH concentration (72.2 ng/ml)

- Finally $10 \%$ has the least effect as there is minimal decrease from actual concentration $(81.5 \mathrm{ng} / \mathrm{ml})$ as shown in table (3) and figures $(15,16$ \& 17).

5. Effect of liquid hand soap on THC-COOH detection \& quantification by GC-MS

- Addition of liquid hand soap in concentration $20 \%$ leading to moderate decrease in concentration of THC-COOH $(66.8 \mathrm{ng} / \mathrm{ml})$.

- While addition of $10 \%$ liquid hand soap decreased in THC-COOH concentration to $(78.3 \mathrm{ng} / \mathrm{ml})$. Finally $5 \%$ has the least effect on THC-COOH as there is minimal decrease from actual conc. $(84.5 \mathrm{ng} / \mathrm{ml})$ As shown in table (4)and figures (18, $19 \& 20)$.

Statistical study for influence of different adulterants on THC-COOH quantification by GC-MS showing that addition of vinegar, drano, bleach, visine and liquid hand soap decreased THC-COOH concentration significantly with increased adulterant concentration as shown in table (5). 
Table (1): Effects of different adulterants on THC metabolites screening by RIA

\begin{tabular}{|c|c|c|c|c|}
\hline Adulterant Conc. & Vinegar & Bleach & Visine & Drano \\
\hline & $24 \mathrm{ng} / \mathrm{ml}$ & Zero & $30 \mathrm{ng} / \mathrm{ml}$ & Zero \\
\hline $\mathbf{4 0} \%$ & Negative & Negative & Negative & Negative \\
\hline \multirow{2}{20\%}{} & $62 \mathrm{ng} / \mathrm{ml}$ & Zero & $41 \mathrm{ng} / \mathrm{ml}$ & Zero \\
\hline \multirow{2}{*}{$\mathbf{1 0} \%$} & Positive & Negative & Negative & Negative \\
\cline { 2 - 5 } & $75 \mathrm{ng} / \mathrm{ml}$ & $11 \mathrm{ng} / \mathrm{ml}$ & $79 \mathrm{ng} / \mathrm{ml}$ & $9 \mathrm{ng} / \mathrm{ml}$ \\
\cline { 2 - 5 } & Positive & Negative & Positive & Negative \\
\hline
\end{tabular}

Table (2): Effects of Liquid hand soap on THC metabolite screening by RIA

\begin{tabular}{|c|c|}
\hline Liquid hand soap & THC \\
\hline $20 \%$ & $\begin{array}{c}\text { Zero } \\
\text { Negative }\end{array}$ \\
\hline $10 \%$ & $\begin{array}{c}\text { Zero } \\
\text { Negative }\end{array}$ \\
\hline $5 \%$ & $\begin{array}{c}\text { Zero } \\
\text { Negative }\end{array}$ \\
\hline
\end{tabular}

Table (3): Effect of different adulterants on THC-COOH detection and quantification by GC MS

\begin{tabular}{|c|c|c|c|c|}
\hline $\begin{array}{c}\text { Adulterant } \\
\text { Conc. }\end{array}$ & Vinegar & Bleach & Visine & Drano \\
\hline \multirow{2}{*}{$\mathbf{4 0} \%$} & $43.3 \mathrm{ng} / \mathrm{ml}$ & $48.6 \mathrm{ng} / \mathrm{ml}$ & $42 \mathrm{ng} / \mathrm{ml}$ & $53.4 \mathrm{ng} / \mathrm{ml}$ \\
\cline { 2 - 5 } & (Positive) & (Positive) & (Positive) & (Positive) \\
\hline \multirow{2}{*}{$\mathbf{2 0} \%$} & $65.2 \mathrm{ng} / \mathrm{ml}$ & $71.3 \mathrm{ng} / \mathrm{ml}$ & $63.6 \mathrm{ng} / \mathrm{ml}$ & $($ Positive $)$ \\
\cline { 2 - 5 } & (Positive) & (Positive) & (Positive) & $81.5 \mathrm{ng} / \mathrm{ml}$ \\
\cline { 2 - 5 } & $79.4 \mathrm{ng} / \mathrm{ml}$ & $80.2 \mathrm{ng} / \mathrm{ml}$ & $77.3 \mathrm{ng} / \mathrm{ml}$ & (Positive) \\
\hline
\end{tabular}

Table (4): Effect of liquid hand soap on THC-COOH detection and quantification by GC.MS

\begin{tabular}{|c|c|}
\hline Liquid hand soap conc. & THC-COOH \\
\hline \multirow{2}{*}{$20 \%$} & $66.8 \mathrm{ng} / \mathrm{ml}$ \\
\cline { 2 - 2 } & (Positive) \\
\hline \multirow{2}{*}{$\mathbf{1 0} \%$} & $78.3 \mathrm{ng} / \mathrm{ml}$ \\
\cline { 2 - 2 } & (Positive) \\
\hline \multirow{2}{*}{$\mathbf{5} \%$} & $84.5 \mathrm{ng} / \mathrm{ml}$ \\
\cline { 2 - 2 } & (Positive) \\
\hline
\end{tabular}

Table (5): Statistical study for influence of adulterants on THC-COOH quantification by GC-MS.

\begin{tabular}{|c|c|c|}
\hline Adulterant & $\begin{array}{c}\text { Sample } \\
\text { Size(N) }\end{array}$ & $\begin{array}{c}\text { Pearson } \\
\text { Correlation }\end{array}$ \\
\hline Vinegar & 12 & -0.763 \\
\hline Bleach & 12 & -0.989 \\
\hline Visine & 12 & -0.891 \\
\hline Drano & 12 & -0.992 \\
\hline Liquid hand soap & 12 & -0.968 \\
\hline
\end{tabular}




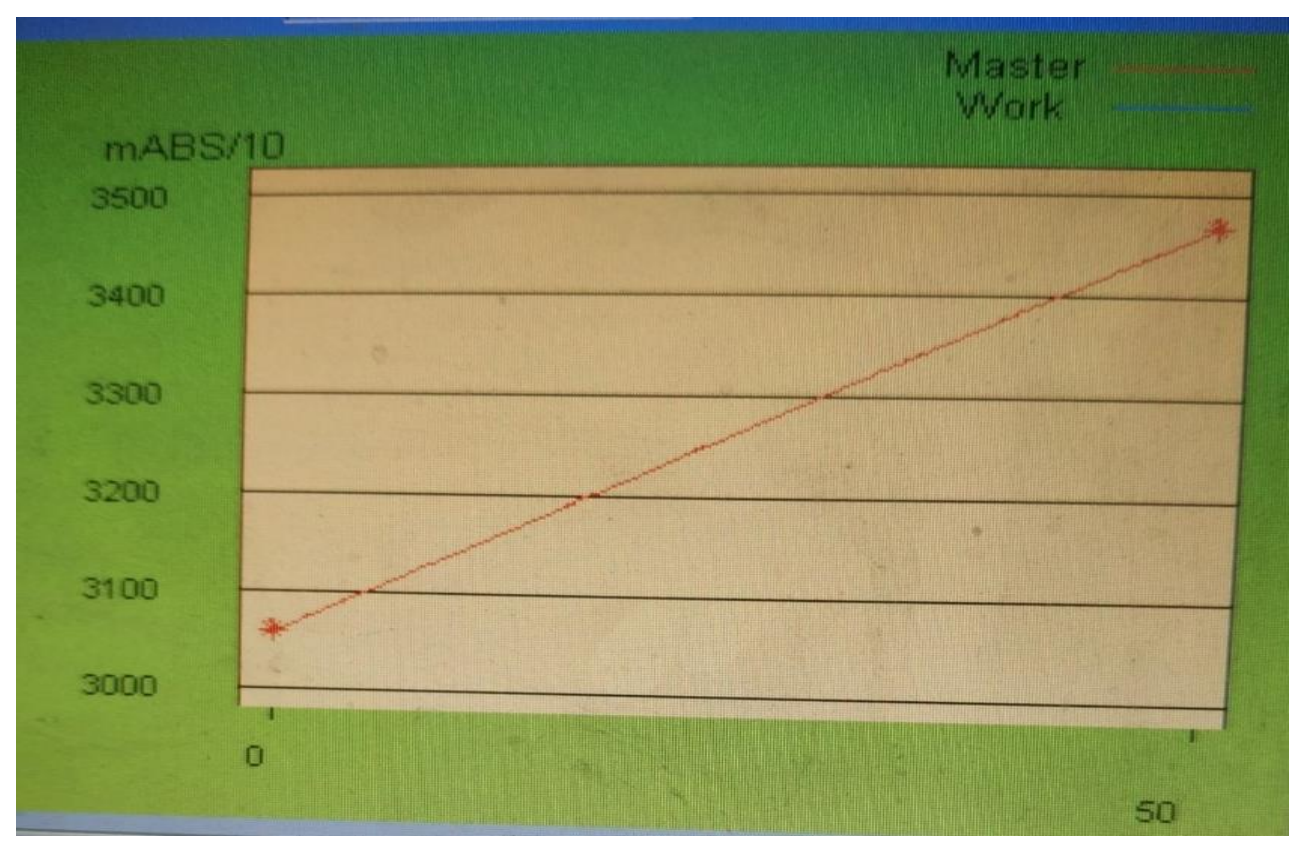

Figure (A): THC calibration curve on Radioimmunoassay.

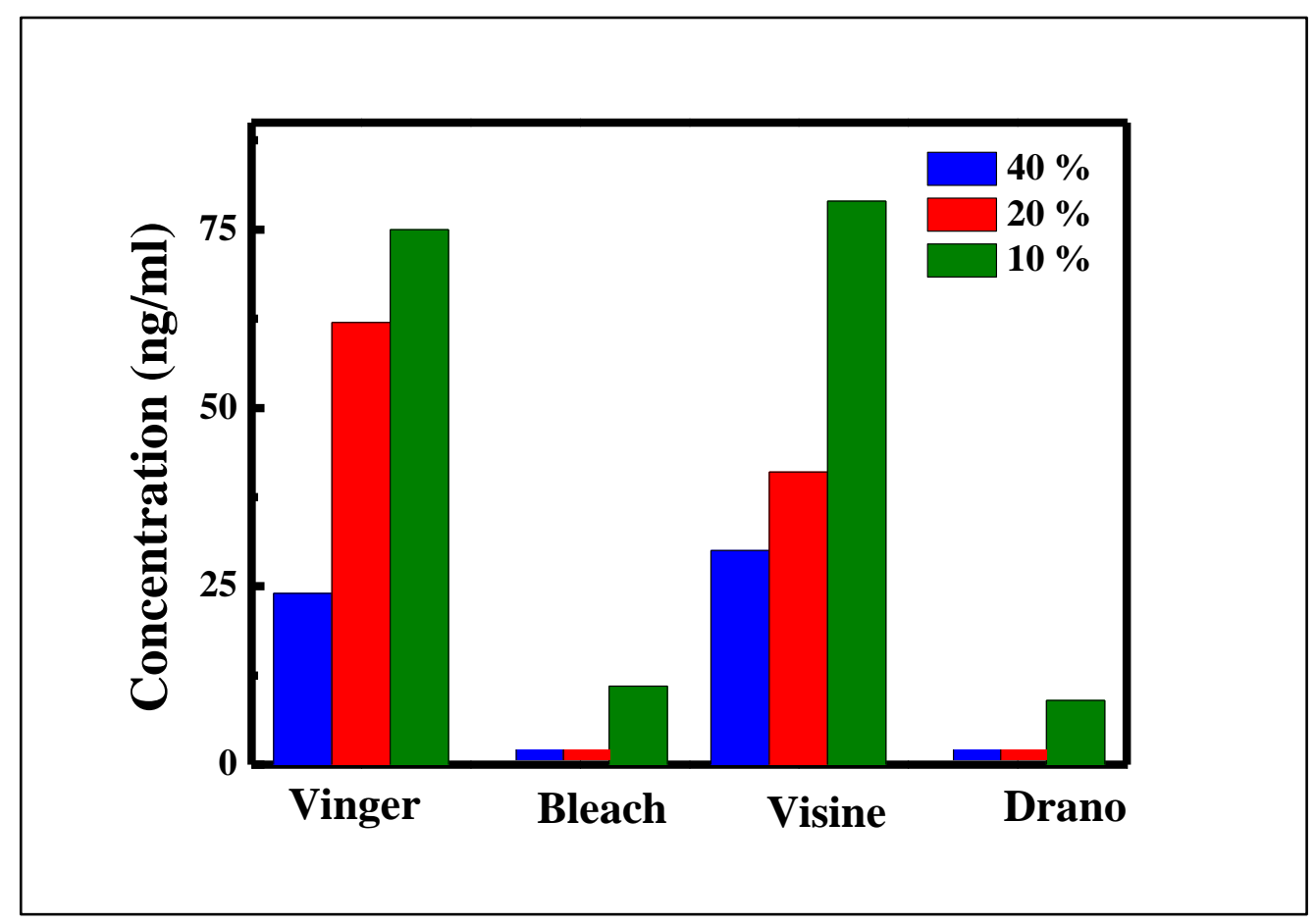

Figure (1): Effects of different adulterants on THC detection by RIA 


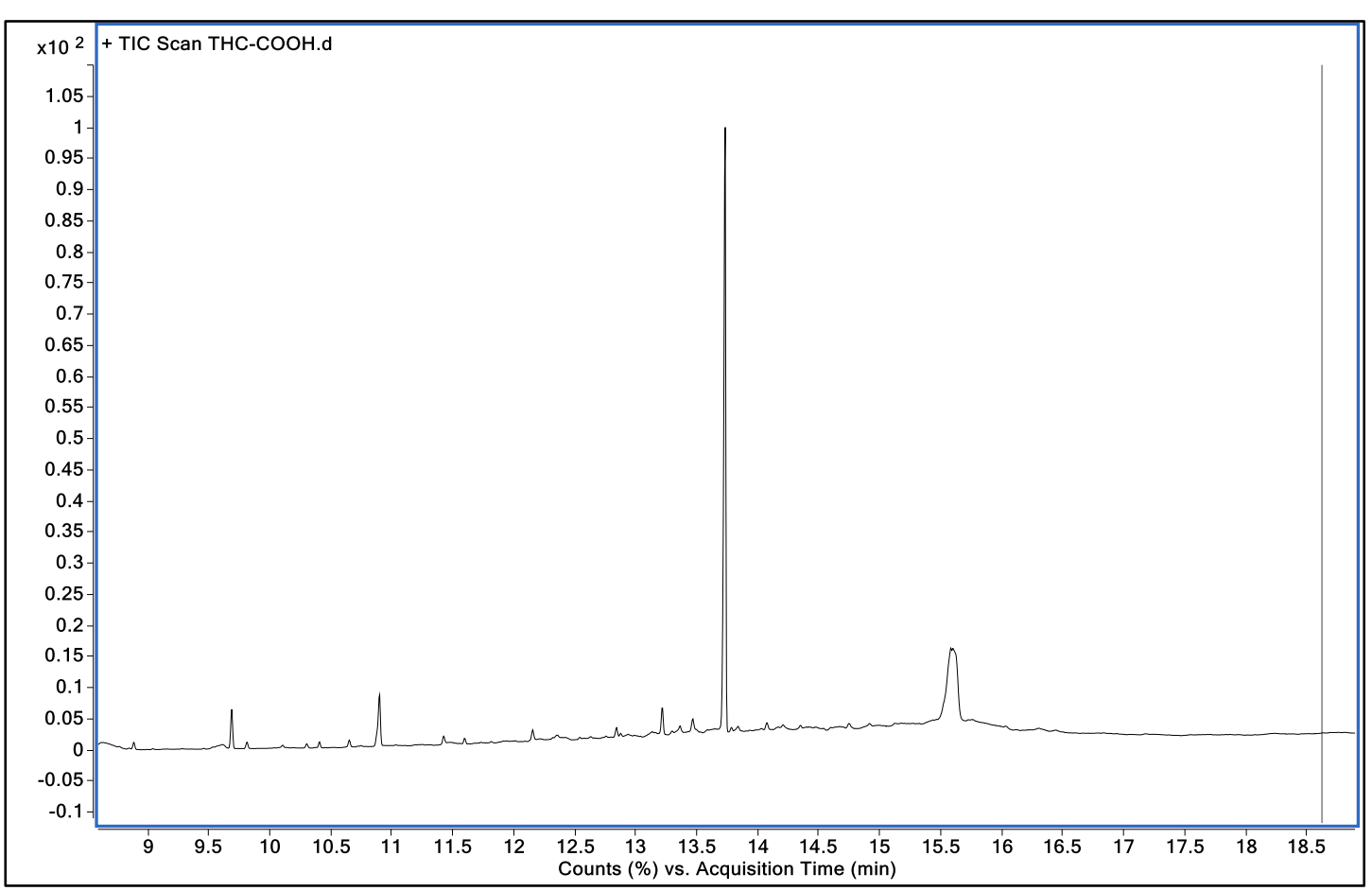

Figure (2): GC-MS chromatogram for the analysis of TMS derivative of THC-COOH

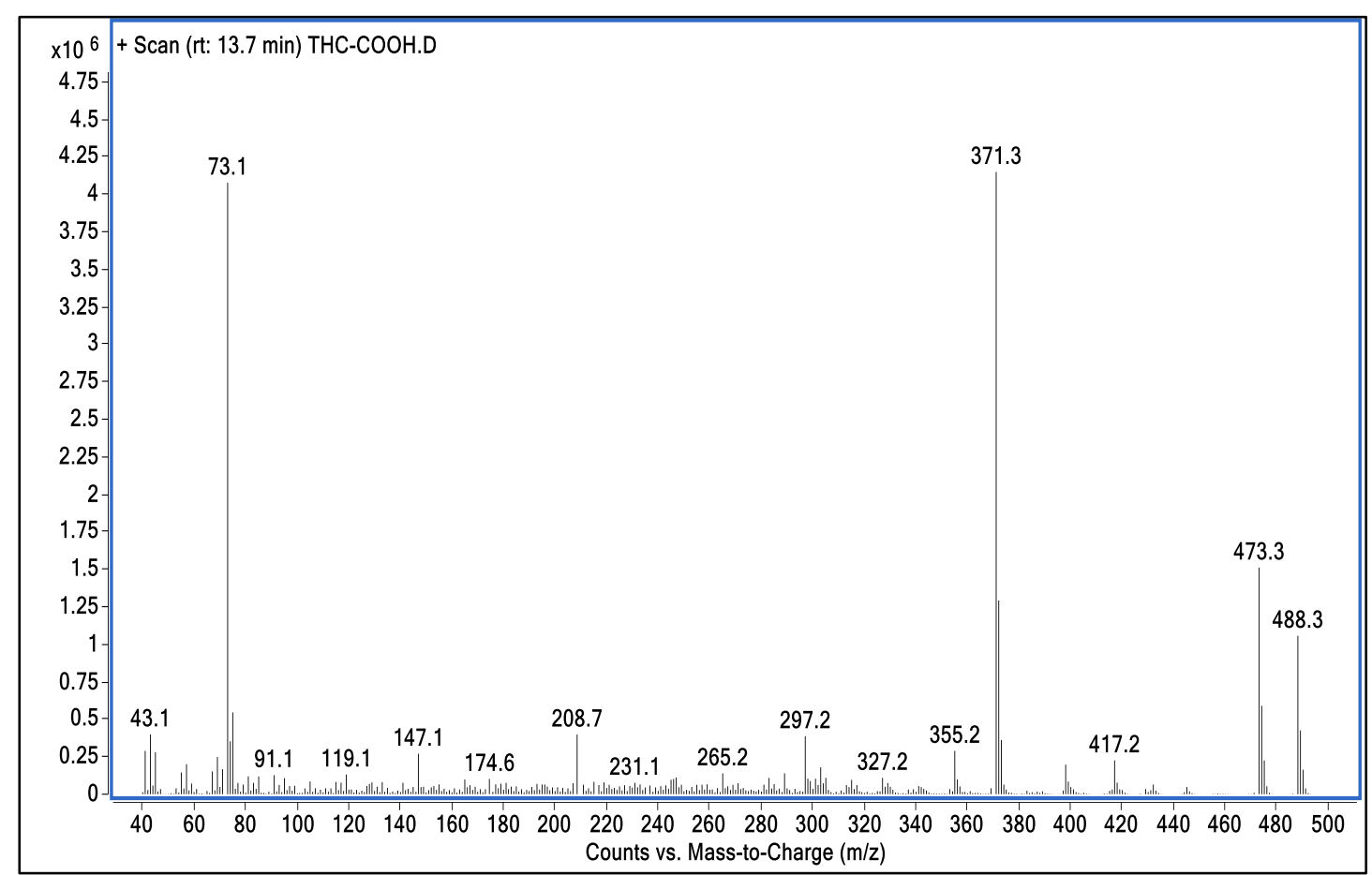

Figure (3): Full scan mass spectrum chromatogram obtained after the analysis of TMS derivative of THC-COOH 


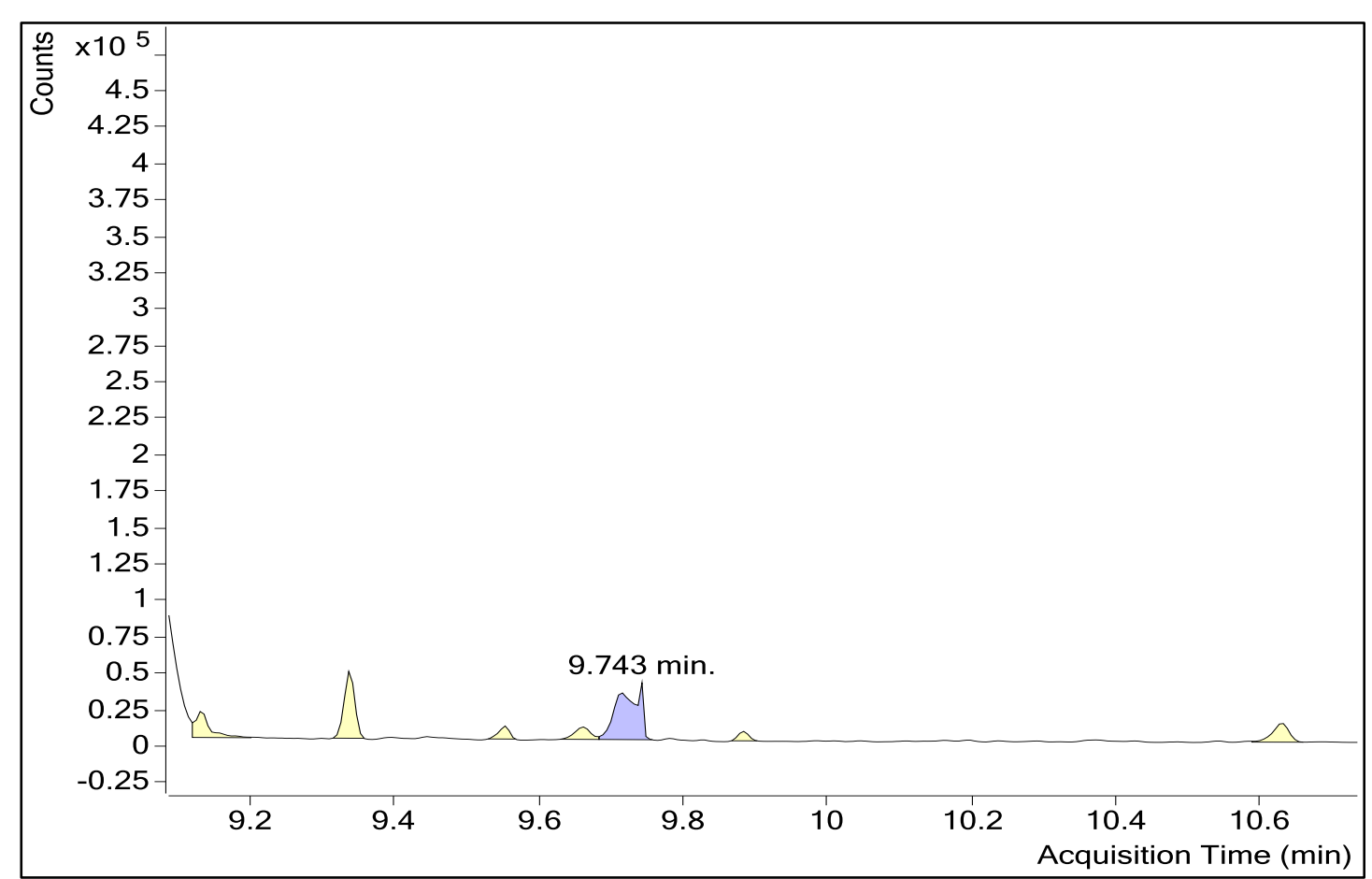

Figure (4): SIM chromatograms obtained after the analysis of blank urine

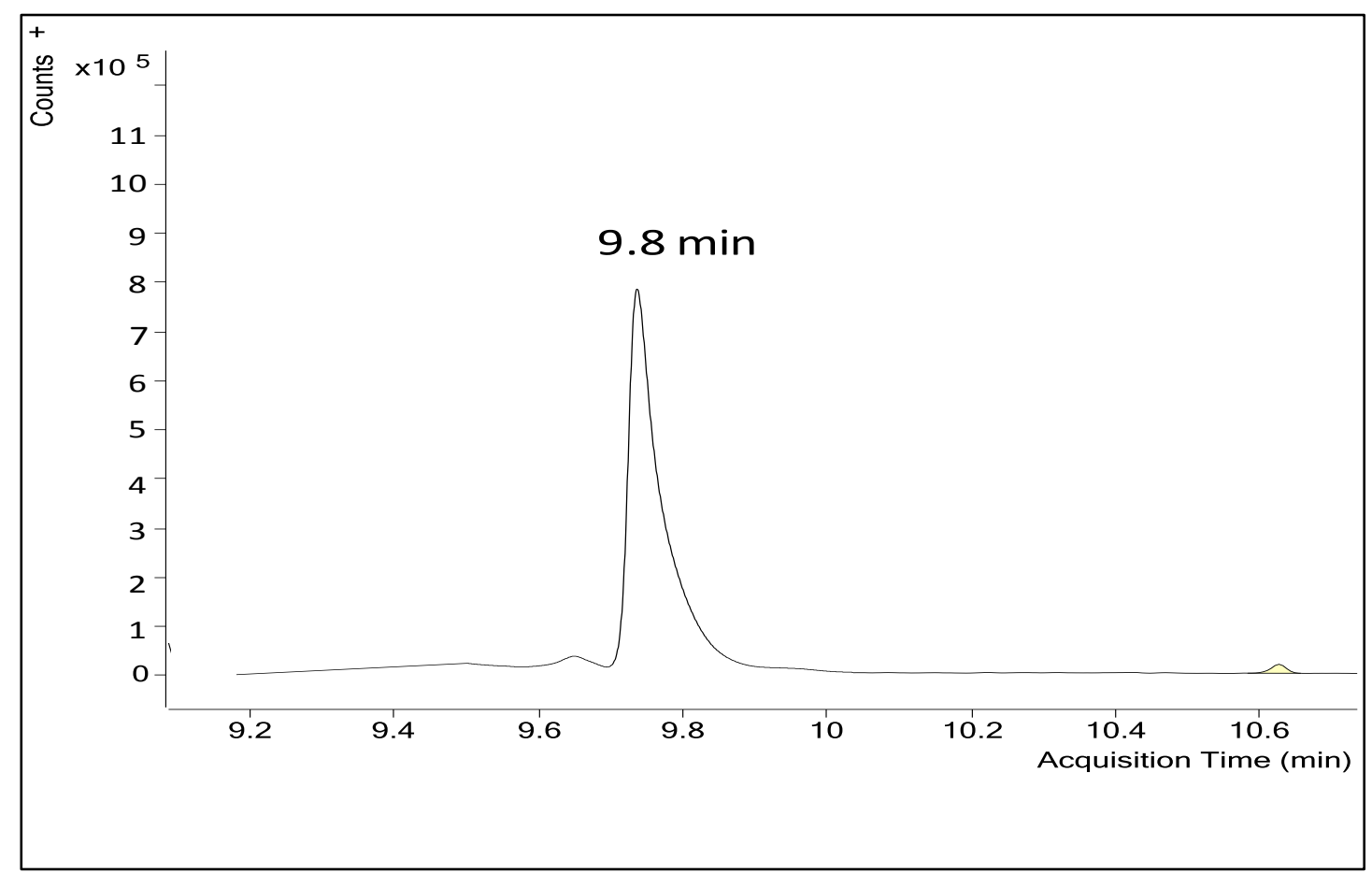

Figure (5): GC-MS chromatograms obtained after the analysis of parent sample (THC-COOH conc $89 \mathrm{ng} / \mathrm{ml}$ ) 


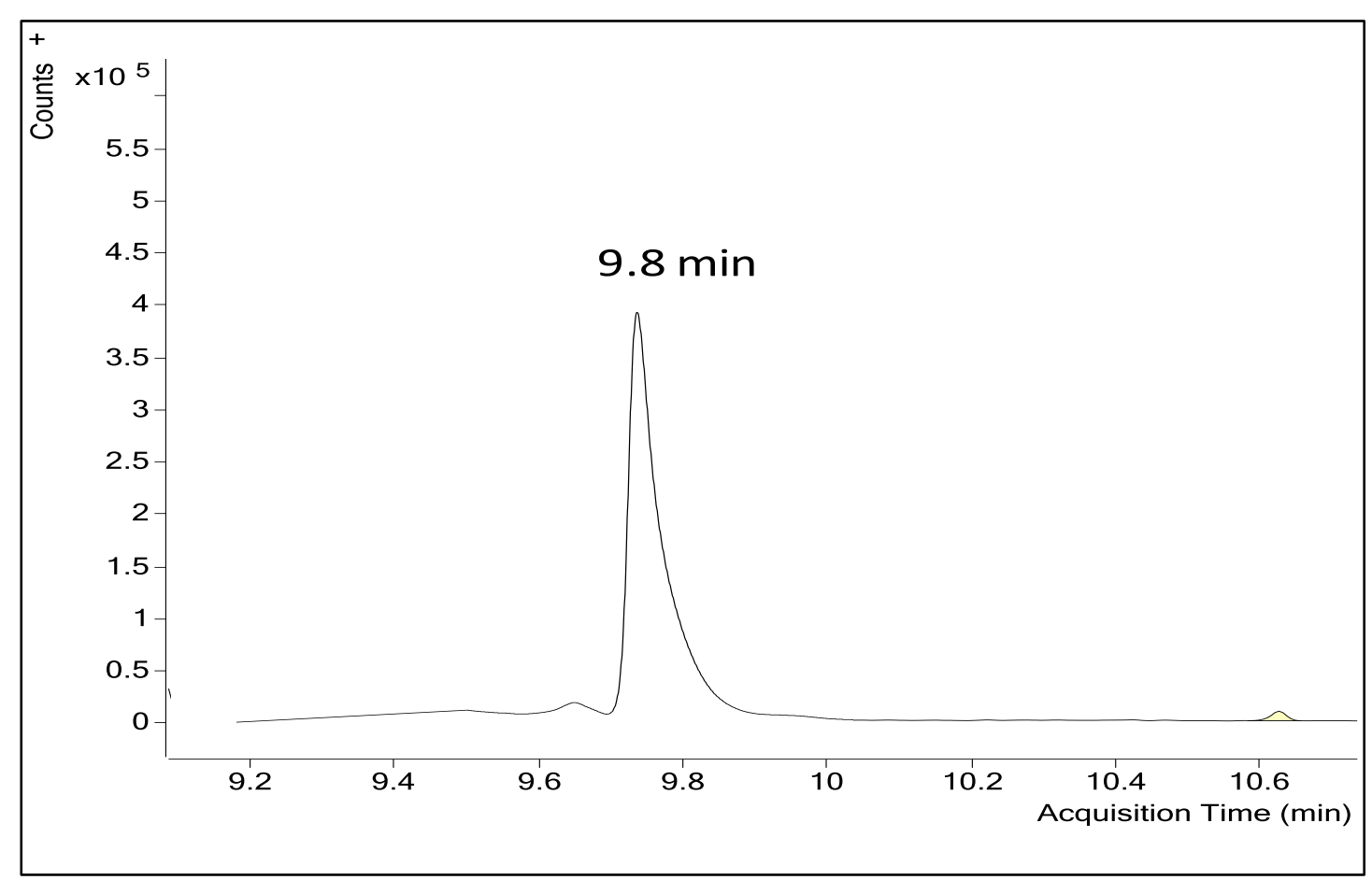

Figure (6): GC-MS chromatogram for parent sample after addition of $40 \%$ vinegar (THC-COOH conc.43.3ng/ml)

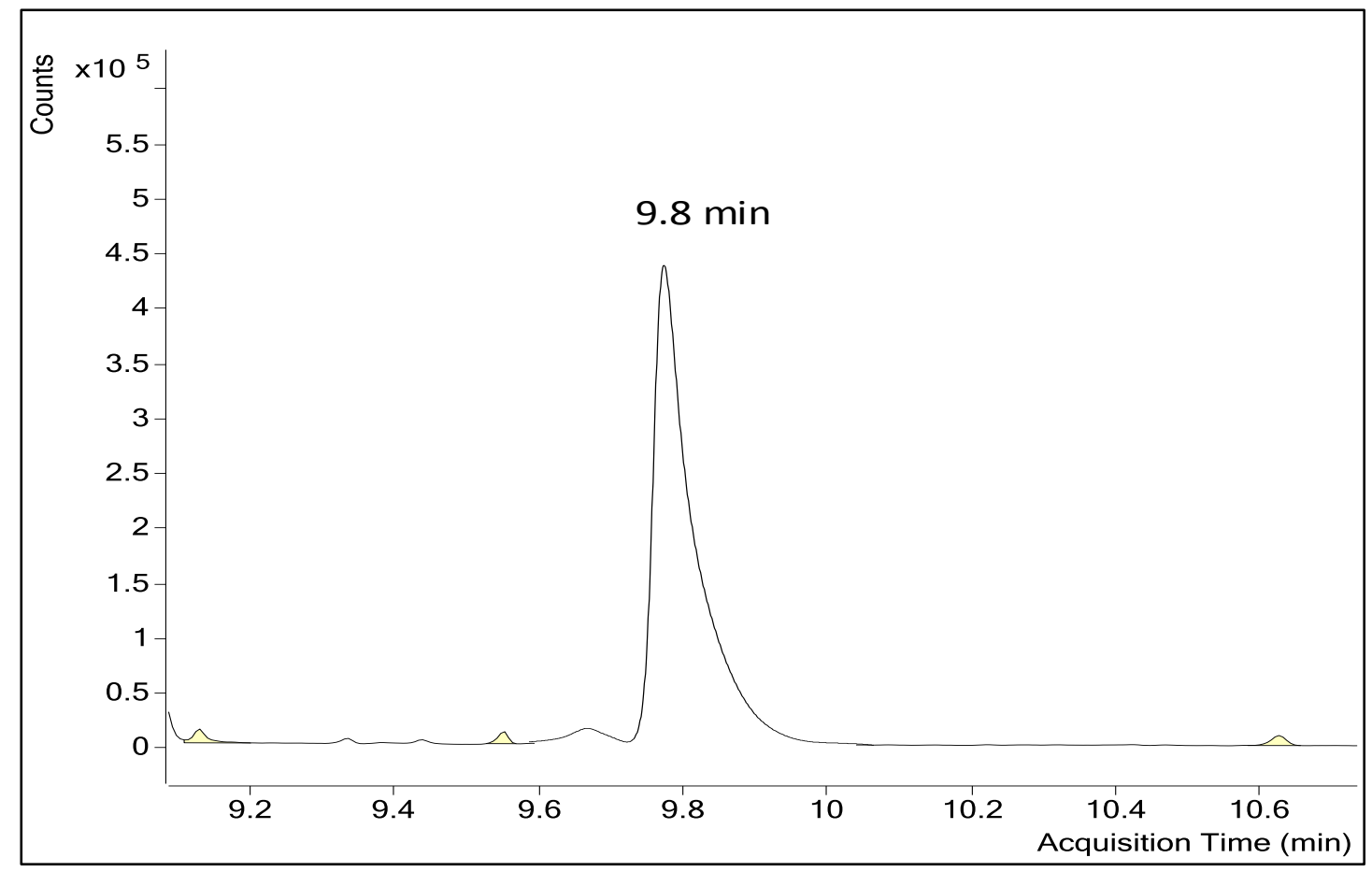

Figure (7): GC-MS chromatogram for parent sample after addition of $20 \%$ vinegar (THC-COOH conc.65.2ng/ml) 


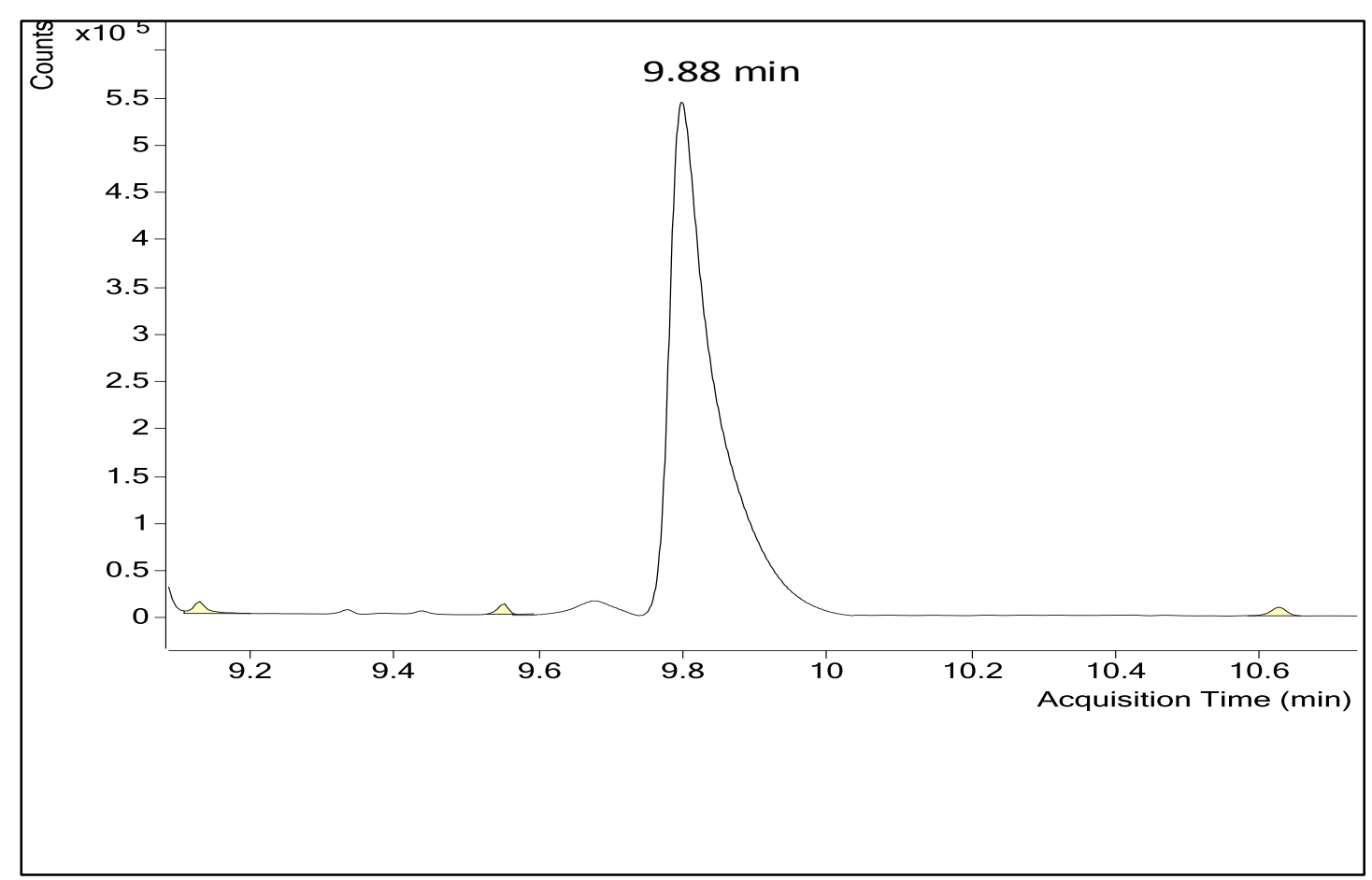

Figure (8): GC-MS chromatogram for parent sample after addition of $10 \%$ vinegar (THC-COOH conc.79.4ng/ml)

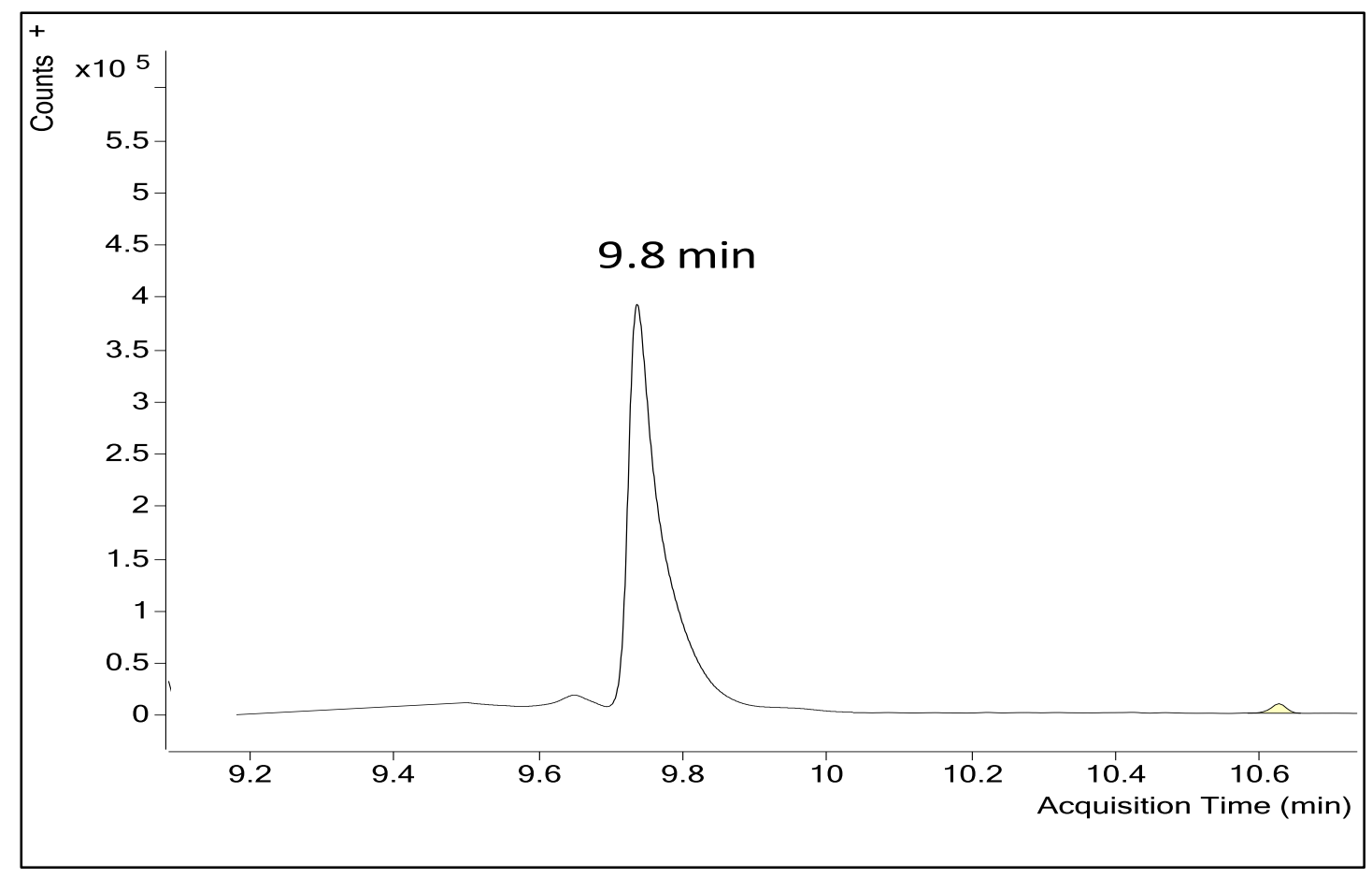

Figure (9): GC-MS chromatogram for parent sample after addition of $\mathbf{4 0} \% \mathrm{bleach}$ (THC-COOH conc.48.6ng/ml) 


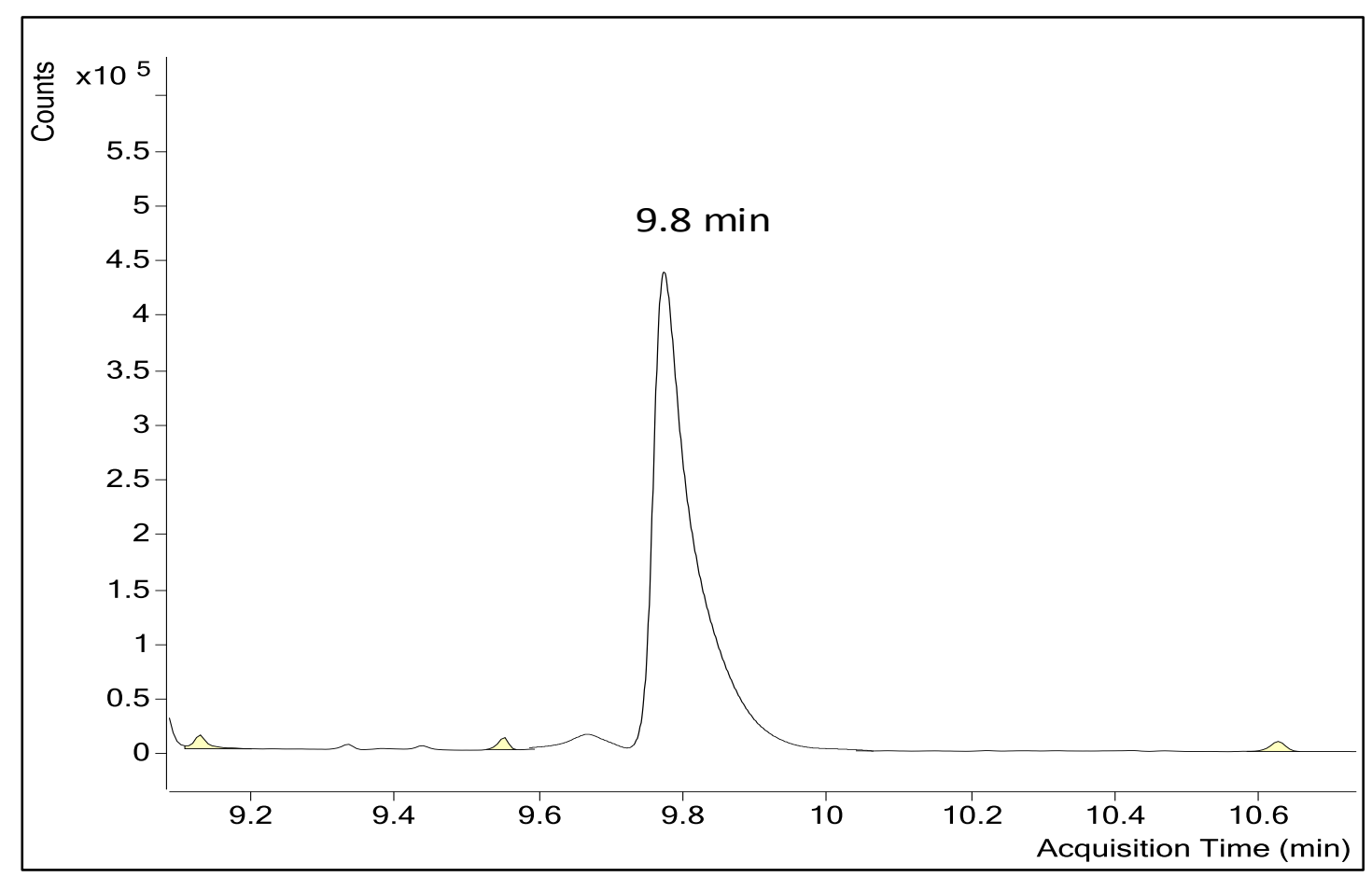

Figure (10): GC-MS chromatogram for parent sample after addition of $20 \%$ bleach (THC-COOH conc.71.3ng/ml)

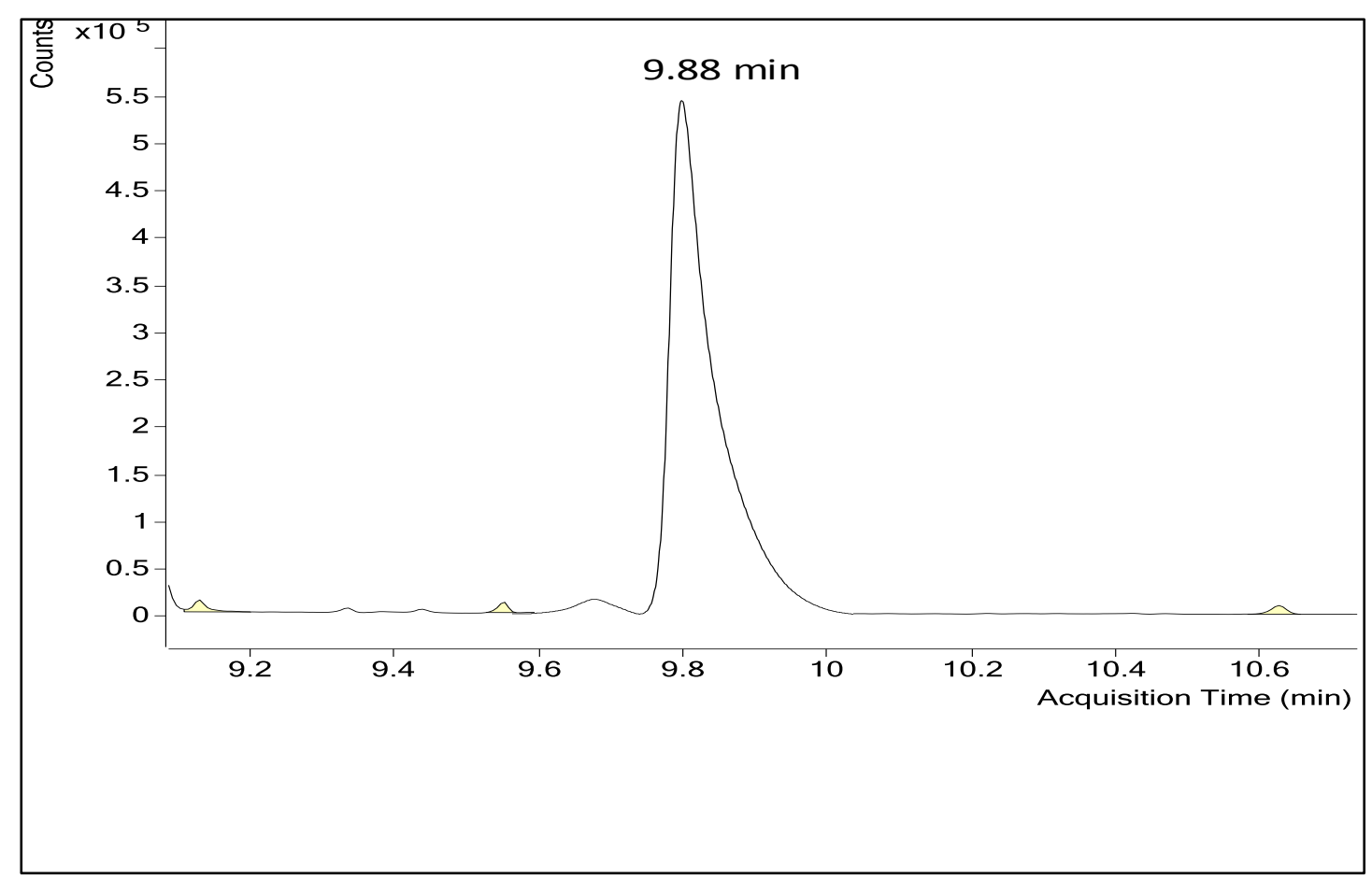

Figure (11): GC-MS Chromatogram for parent sample after addition of $10 \%$ bleach (THC-COOH conc.82.2ng/ml) 


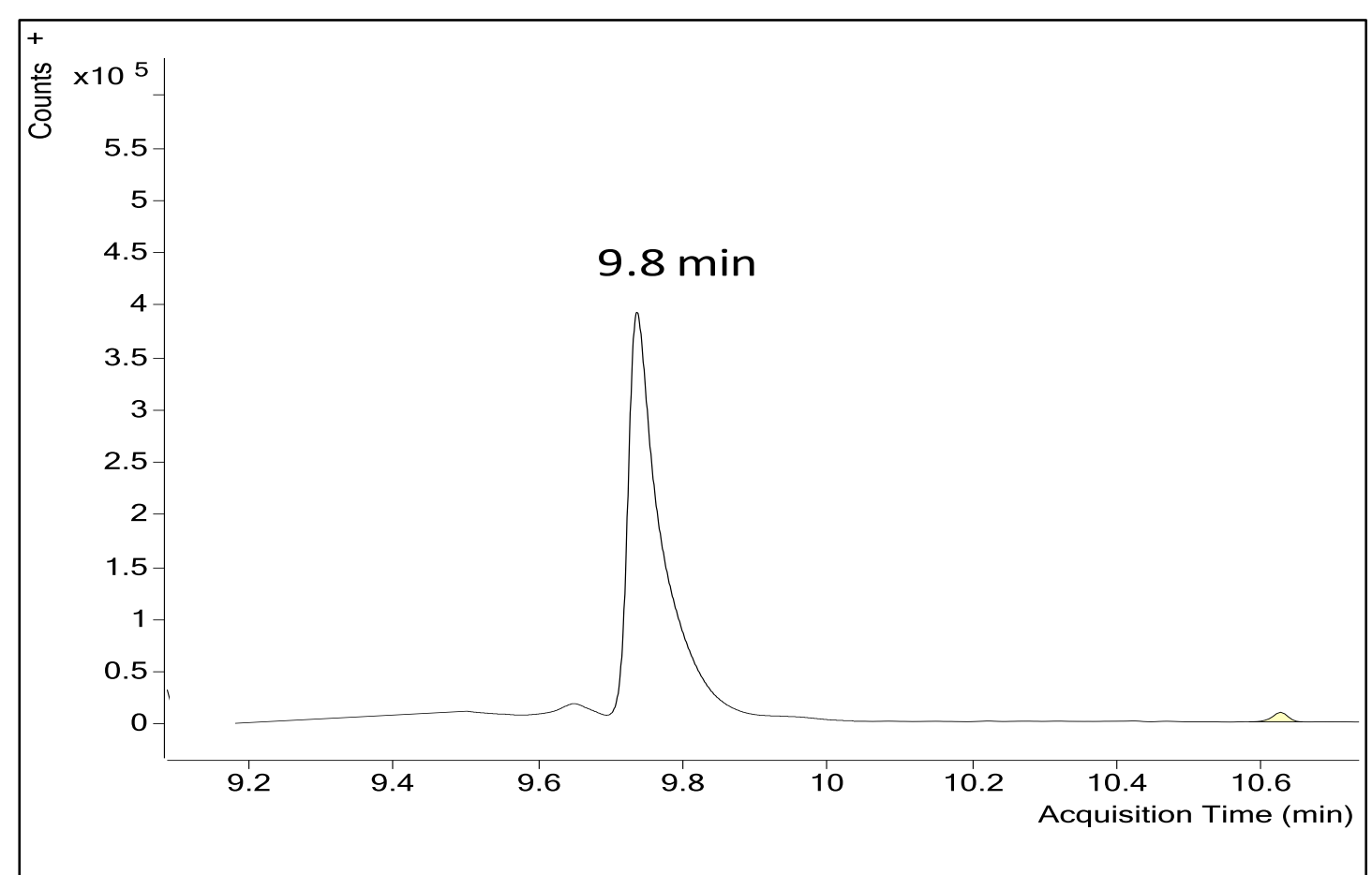

Figure (12): GC-MS chromatogram for parent sample after addition of $40 \%$ visine (THC-COOH conc.42ng/ml)

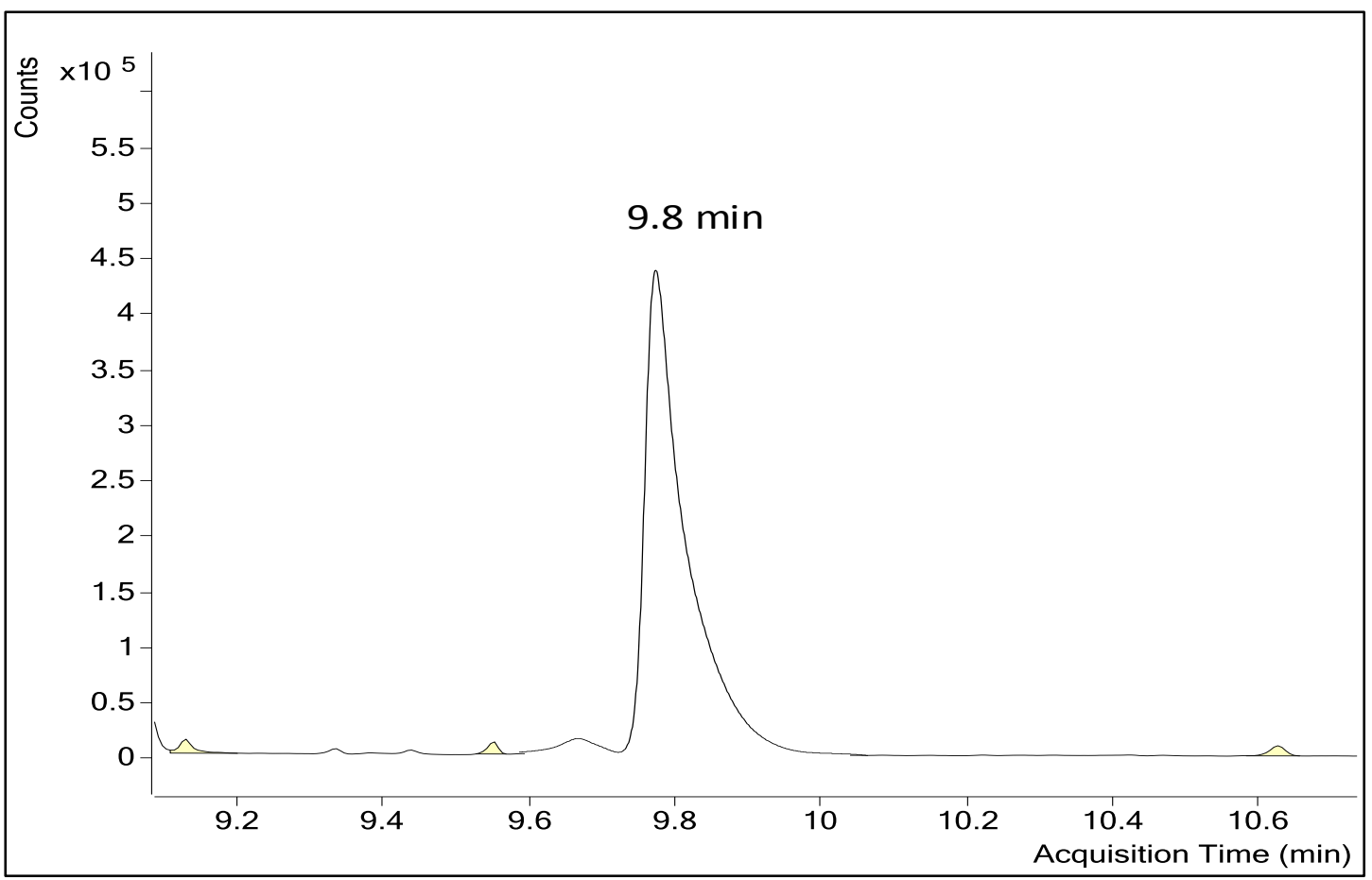

Figure (13): GC-MS Chromatogram for parent sample after addition of $20 \%$ visine (THC-COOH conc.63.6ng/ml) 


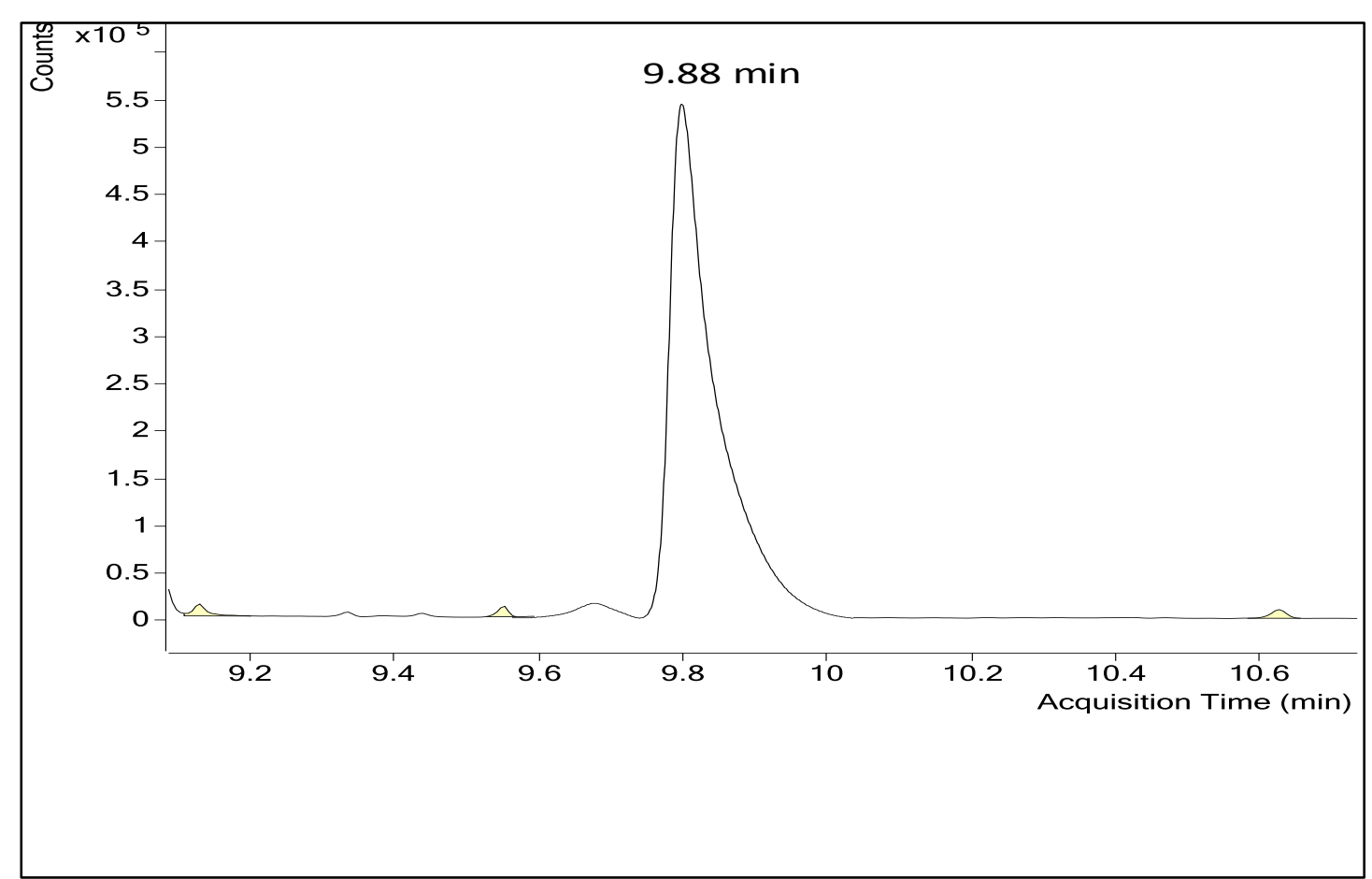

Figure (14): GC-MS Chromatogram for parent sample after addition of $10 \%$ visine (THC-COOH conc.77.3ng/ml)

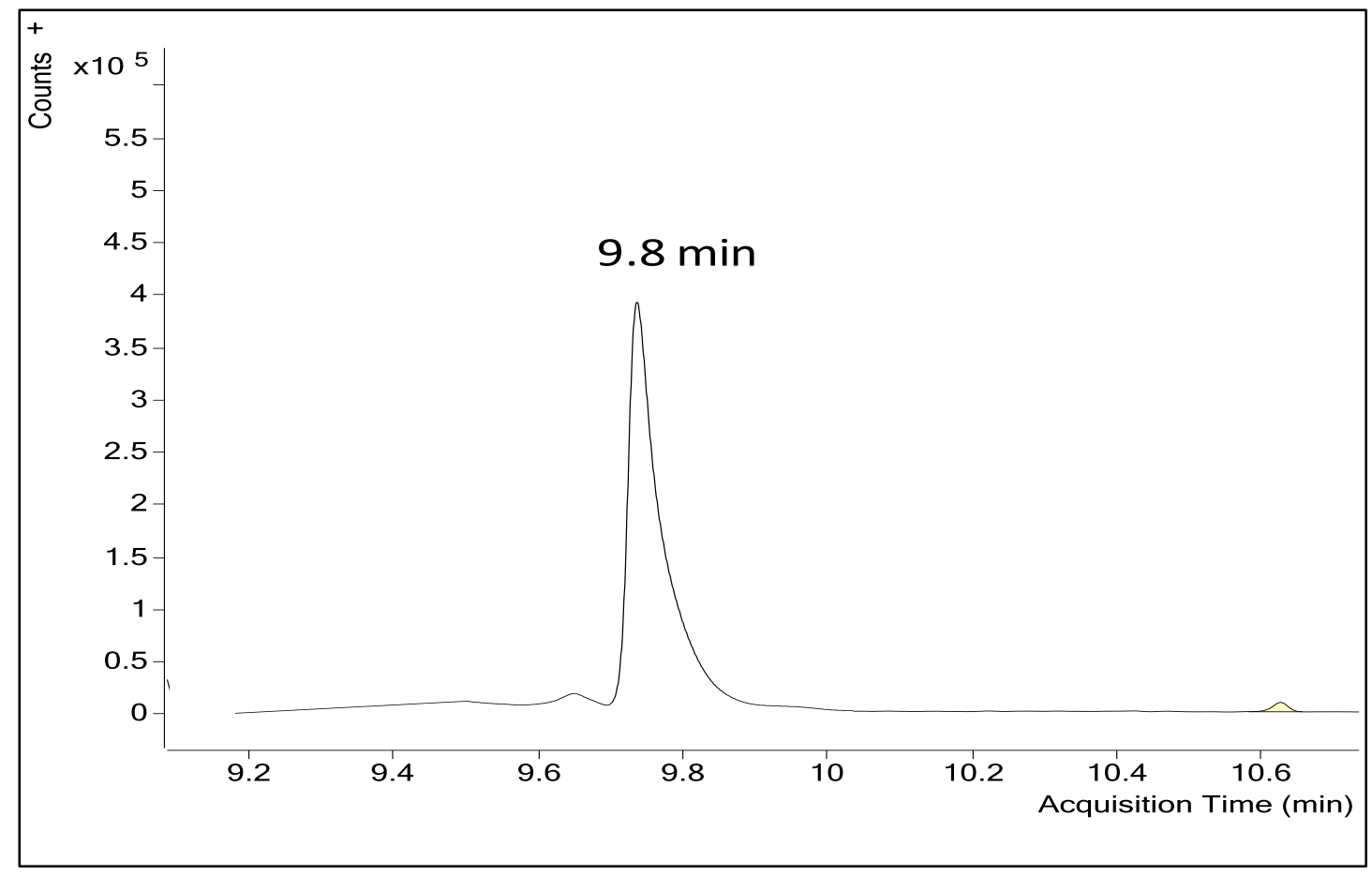

Figure (15): GC-MS chromatogram for parent sample after addition of $\mathbf{4 0} \%$ drano (THC-COOH conc.53.4ng/ml) 
Figure (16): GC-MS Chromatogram for parent sample after addition of $20 \%$ drano (THC-COOH conc.72.2ng/ml)

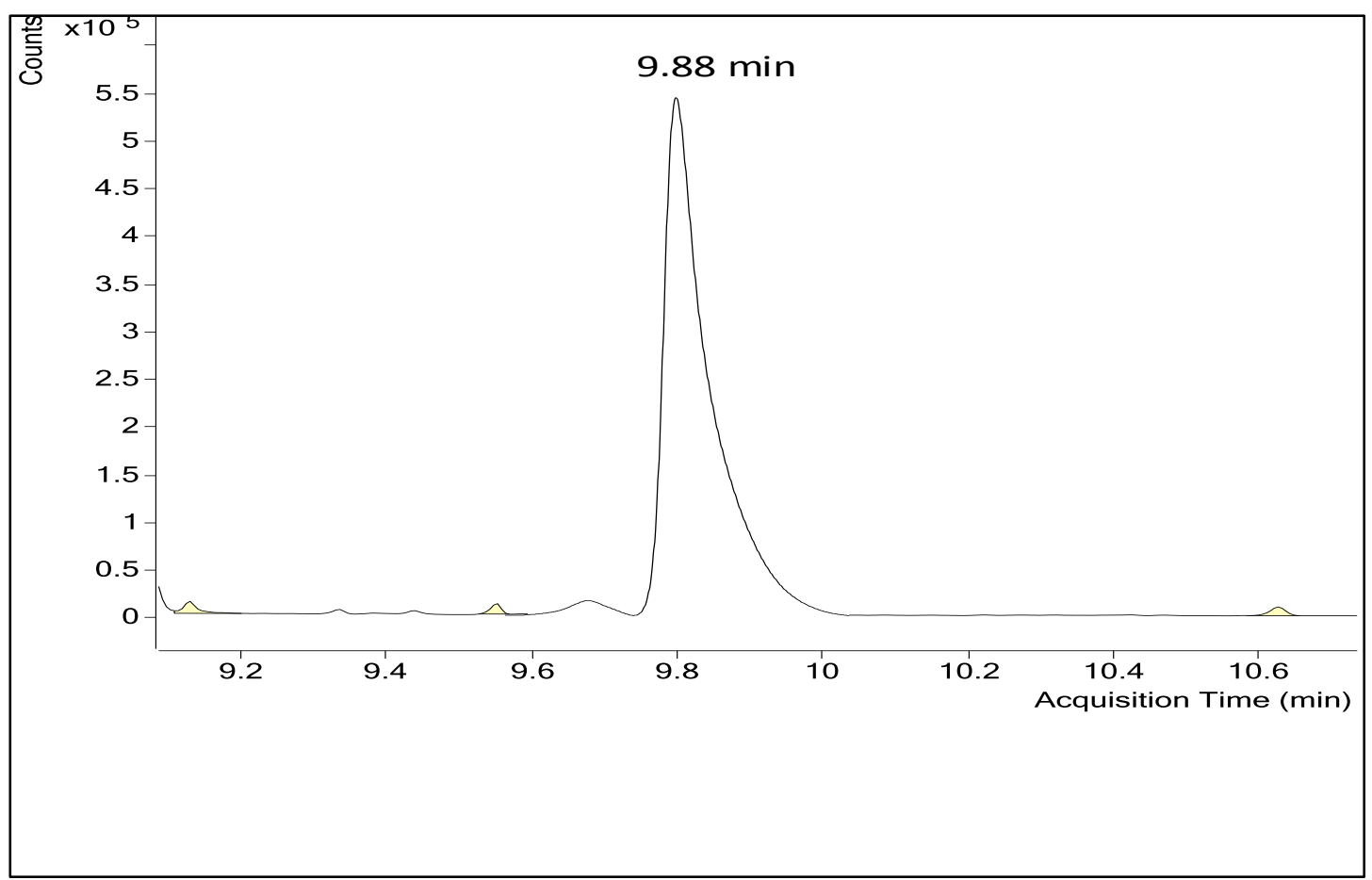

Figure (17): GC-MS chromatogram for parent sample after addition of $10 \%$ drano (THC-COOH conc.81.5ng/ml) 


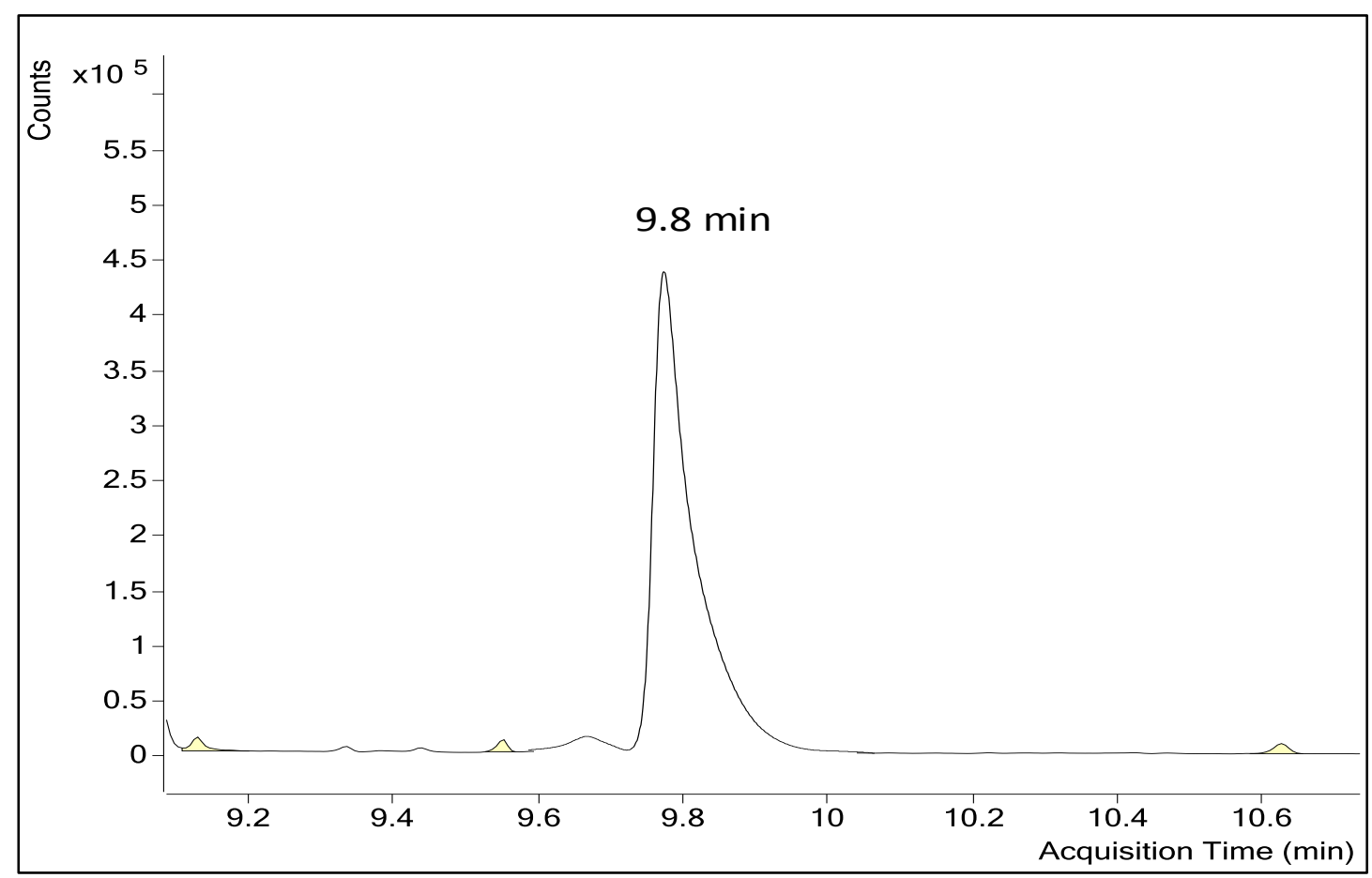

Figure (18): GC-MS Chromatogram for parent sample after addition of $20 \%$ liquid hand soap (THC-COOH conc.66.8ng/ml)

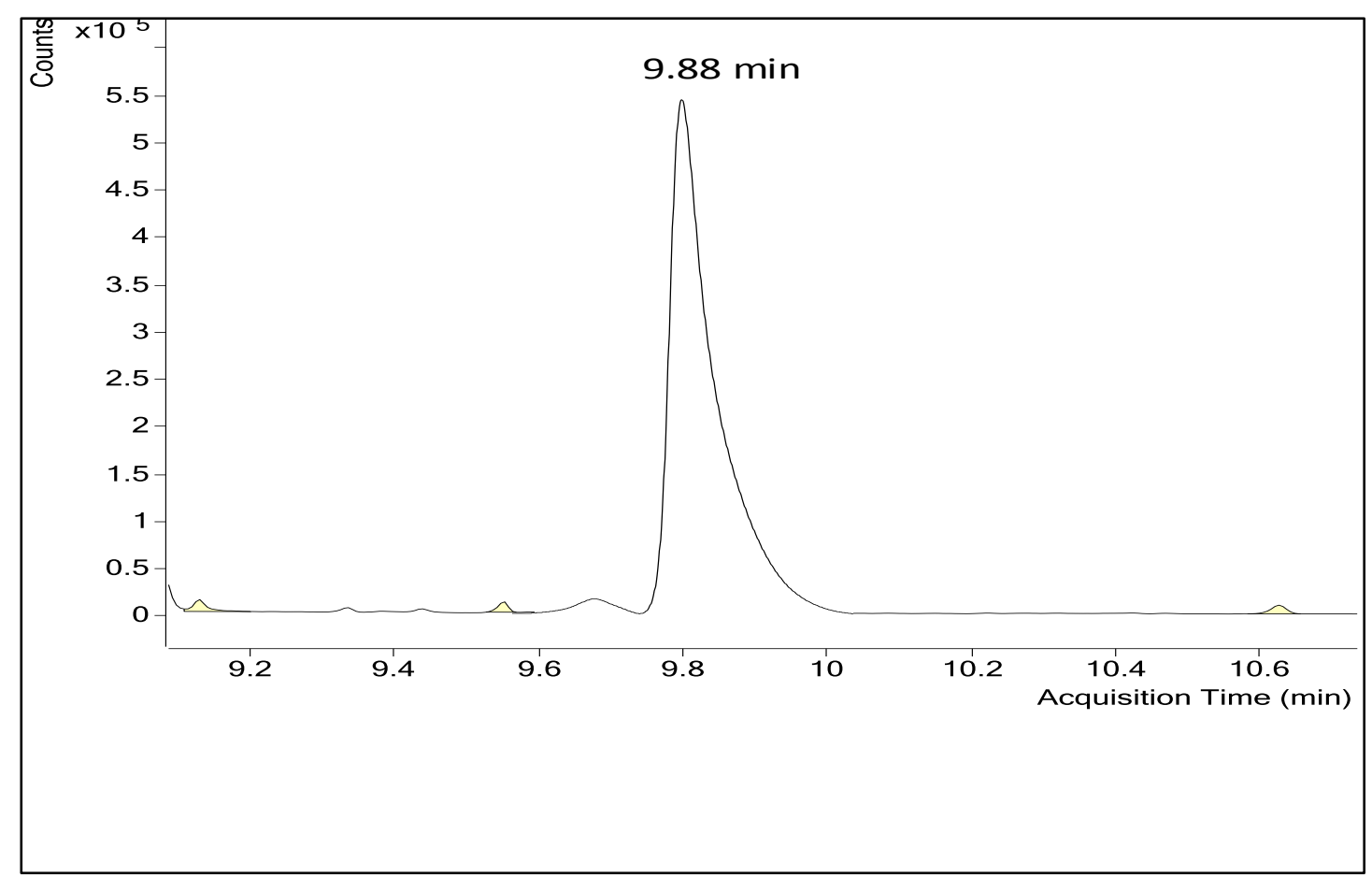

Figure (19): GC-MS chromatogram for parent sample after addition of $10 \%$ liquid hand soap (THC-COOH conc.78.3ng/ml) 


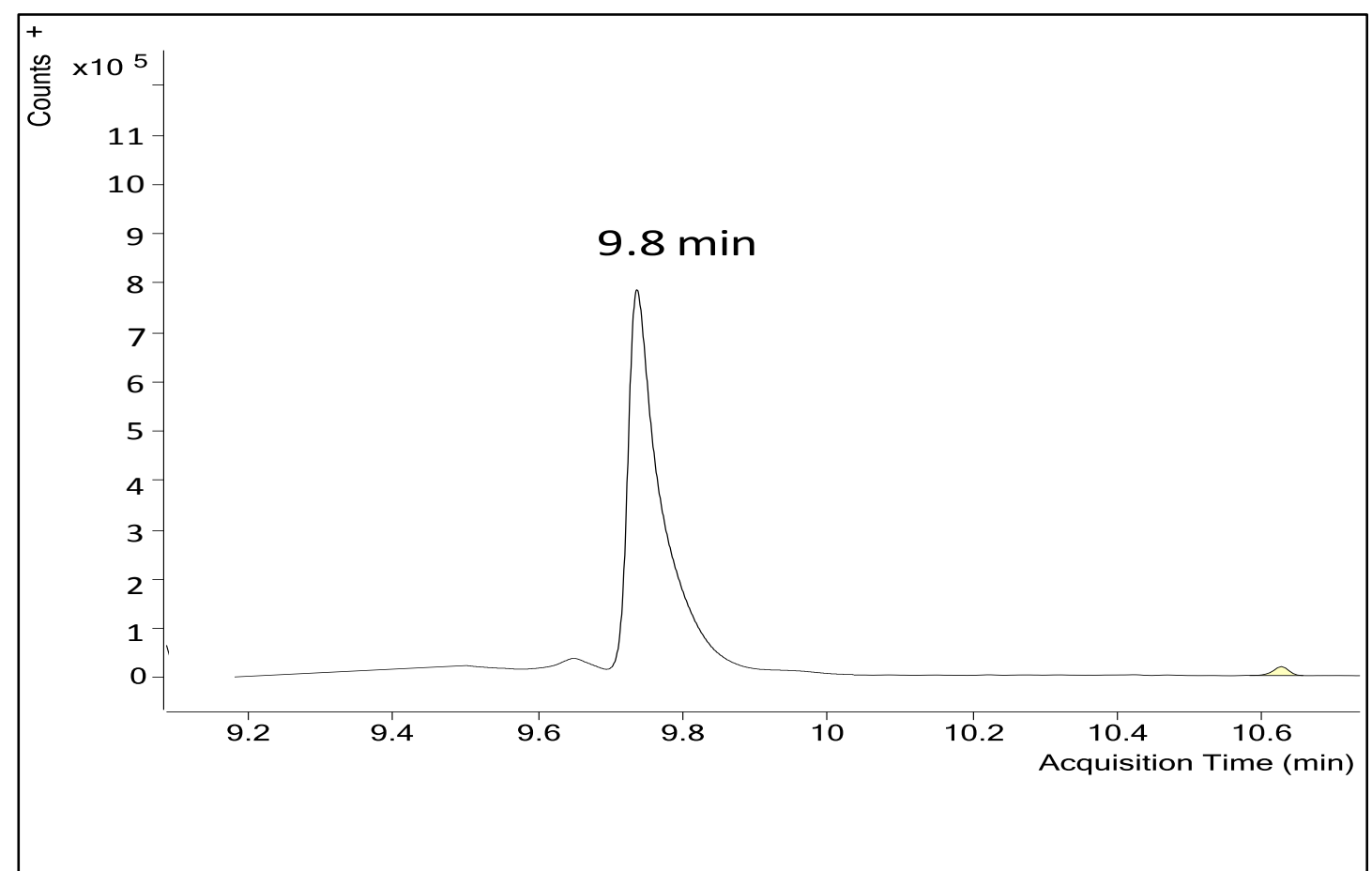

Figure (20): GC-MS chromatogram for parent sample after addition of $5 \%$ liquid hand soap (THC-COOH conc.84.5ng/ml)

\section{Discussion}

Effect of different urine adulterants on radioimmunoassay screening for cannabis:

Addition of vinegar at high concentration $40 \%$ was able to successfully masking positive response of cannabis in tested urine samples, while moderate and low concentration $(20 \%, 10 \%)$ didn't affect cannabis detection in urine samples.

This was in agreement with Dasgupta, (2010) who report that vinegar is effective adulterant for many drugs of abuse as cannabis.

Addition of bleach whatever its concentration was able to mask cannabis detection by immunoassay.

These results were in agreement with Uebel and Wium, (2002) who reported that bleach at high concentration can decrease response rate for cannabis by immunoassay techniques

Addition of visine at concentration $40 \%$ and $20 \%$ was able to successfully masking positive response of cannabis in tested urine while $10 \%$ had no effect.

The active ingredient in Visine eye drops is tetrahydrozo-line hydrochloride, which relieves redness and irritation by constricting blood vessels. However, Dasgupta, (2007) found that the mechanism of adulteration is most likely due to the inactive ingredients benzalkoniumchloride and borate.

Similar to Jaffee et al., (2007) uptake of THC through benzalkoniumchloride reduces the binding in immunoassay drug screens, causing false-negative results on immunoassays.

Addition of drano by any concentration was able to mask cannabis detection by immunoassay. Also addition of liquid hand soap by any concentration even low concentration up to $5 \%$ masked cannabis detection by immunoassay giving false negative results.
These results were in agreement with Uebel and Wium, (2002) who reported that drano is very effective in masking cannabis detection by immunoassay techniques. Also in consistent with Bronner et al., (1990) and $W u$, (2003) who stated that hand soap detergent adulteration has caused false-negative results across a variety of drug assays using the cloned enzyme donor immunoassay (CEDIA) including screens for THC, amphetamine, barbiturates, cocaine, opiates, and PCP. Effect of different adulterants on THC-COOH detection and quantification by GC-MS:

Addition of vinegar in conc. $40 \%$ leading to decrease in concentration of THC-COOH to more or less half the actual concentration $(43.3 \mathrm{ng} / \mathrm{ml})$. While addition of $20 \%$ vinegar decreased $\mathrm{THC}-\mathrm{COOH}$ cconcentration.to $(65.2 \mathrm{ng} / \mathrm{ml})$. Finally addition of $10 \%$ vinegar had the least effect as there was minimal decrease from actual concentration $(79.4 \mathrm{ng} / \mathrm{ml})$.

This was in agreement with $W u$ et al., (1999) who noticed considerable decrease in $\mathrm{THC}-\mathrm{COOH}$ at a lower $\mathrm{pH}$.

Addition of bleach in concentration $40 \%$ decreased THC-COOH concentration to $(48.6 \mathrm{ng} / \mathrm{ml})$. While addition of $20 \%$ bleach decreased THC-COOH concentration to $(71.3 \mathrm{ng} / \mathrm{ml})$. Finally $10 \%$ bleach has the least effect as there is minimal decrease from actual concentration $(80.2 \mathrm{ng} / \mathrm{ml})$.

This means that change in $\mathrm{pH}$ either by increase or decrease can affect THC-COOH concentration by GC-MS.Similar to Baiker et al., (1994) who reported that bleach adulteration of urine samples caused a decreased concentration of $\mathrm{THC}-\mathrm{COOH}$ as measured by $\mathrm{GC} / \mathrm{MS}$. 
Addition of visine in concentration $40 \%$ decreased THC-COOH concentration to $(42 / \mathrm{ml})$, while addition of $20 \%$ visine decreased $\mathrm{THC}-\mathrm{COOH}$ concentration to $(63.6 \mathrm{ng} / \mathrm{ml})$. Finally $10 \%$ has the least effect as there is minimal decrease from actual concentration $(77.3 \mathrm{ng} / \mathrm{ml})$

In consistent with Dasgupta, (2007) who stated that visine has been reported to cause marked adulterating effects on THC-COOH by GC-MS

Addition of drano in conc. $40 \%$ leading to decrease in concentration of $\mathrm{THC}-\mathrm{COOH}$ to $(53.4$ $\mathrm{ng} / \mathrm{ml}$ ). While addition of $20 \%$ drano caused decrease in THC-COOH concentration $(72.2 \mathrm{ng} / \mathrm{ml})$. Finally $10 \%$ has the least effect as there is minimal decrease from actual concentration $(81.5 \mathrm{ng} / \mathrm{ml})$.

In consistent with Fu et al., (2014), Drano may affect GC-MS confirmation method for THC-COOH.

Addition of liquid hand soap in concentration $20 \%$ leading to moderate decrease in concentration of THC-COOH $(66.8 \mathrm{ng} / \mathrm{ml})$. While addition of $10 \%$ liquid hand soap cause decreased in THC-COOH conc. to $(78.3 \mathrm{ng} / \mathrm{ml})$. Finally $5 \%$ has the least effect on THC$\mathrm{COOH}$ as there is minimal decrease from actual concentration $(84.5 \mathrm{ng} / \mathrm{ml})$.

In consistent with $W u$ et al., (1999), in the gas chromatographic-mass spectrometric (GC-MS) confirmation method, oxidizing agents as sodium hypochlorite in liquid hand soap interfere with the detection of THC-COOH.

The major problem which faced during examination of samples was the loss of THC-acid and the internal standard in the extraction process. To alleviate this problem, reducing agents as sodium hydrosulfite or sulfamic acid can be used. These methods only allowed detection of the remaining THC-acid in the urine. Generally, to save the drug from the oxidizing agents, addition of carbonate as buffering agent prior to or following urine void was also suggested.

\section{Conclusion}

The current study concludes that some adulterants make it easy to produce false negative results on RIA testing for cannabis and GC-MS is important to overcome adulteration methods in urine analysis.

\section{References}

Baiker C., Serrano L.. and Lindner B. (1994): Hypochlorite adulteration of urine causing decreased concentration of delta-9-THC-COOH by GC/MS. J Anal Toxicol.18: 101-103.

Bronner W., Nyman P. and Minden D.(1990): Detectability of phencyclidine and 11-nordelta9 tetrahydrocannabinol-9 carboxylic acid in adulterant urine by RIA and flouresence polarization immunoassay. J. Anal. Toxicol. 14(6):368-371.

Dasgupta A., (2010): Household Chemicals and Internet Based Products for Beating Urine Drug Tests. In: Beating drug tests and defending positive results.ch (5):61-78

Dasgupta A., (2007): The effects of adulterants and selected ingested compounds on drugs-of-abuse testing in urine. Am J Clin Pathol. 128(3):491-503.
Fu S., Luong S., Pham A., Charlton N. and Kuzhiumparambil U. (2014): Bioanalysis of urine samples after manipulation by oxidizing chemicals: Technical considerations. Bioanalysis. 6: 1543.

Grotenhermen F. and Russo E. (2002): Cannabis and Cannabinoids: Pharmacology, Toxicology, and Therapeutic Potential. Pharmacol.7:1-20.

Hall W. and Degenhardt L. (2015): High potency cannabis: a risk factor for dependence, poor psychosocial outcomes, and psychosis. B.M.J. 350: 1205-1206.

Hamdi E., Sabry N., Sedrak A., Khowailed A. and Loza N. (2016): Sociodemographic Indicators for Substance Use and Abuse in Egypt. J. Addiction Prevention. 4(1):8.

Hammam R., Zalat M., Abdelsalam N., and Mesallam D., (2018): Substance abuse and driving behavior among professional minibus drivers at Zagazig city, Sharqia governrate, Egypt. Egyptian Journal of Occupational Medicine.42 (3): $365-382$

Jaffee B. W., Trucco E., Levy S., and Weiss R. (2007): Is this urine really negative? A systematic review of tampering methods in urine drug screening and testing .Journal of Substance Abuse Treatment. 33(1):33-42.

Kassebaum, N., Arora, M., and Barber, R. (2015): Global, regional, and national disabilityadjusted life-years (DALYs) for 315 diseases and injuries and healthy life expectancy (HALE), 1990-2015: a systematic analysis for the Global Burden of Disease Study .Lancet.388:1603-1658.

Radwan M., Ross S., Slade D., Ahmed, S., Zulfiqar F.and Elsohly M. (2008): Isolation and characterization of new Cannabis constituents from a high potency variety. Planta Med.74 (3): 267-272.

Rainey, P.M. and Baird, G.S. (2012): Analytical methodologies for the toxicology laboratory. In: Clinical toxicology testing: A guide for laboratory professionals. Magnani, B. Bissell, M. and Wong, T, et al. editors. Northfield (IL):ch (4). CAP Press: 83-96.

Saleh D., Irene A. Christofer A. (2015): Substance use by Egyptian youth: current patterns and potential avenues for prevention. Substance Use \& Misuse J.,50(5):609-618.

Uebel R.. and Wium C.(2002): Toxicological screening for drugs of abuse in samples adulterated with household chemicals. S Afr. Med. J.92:547-549.

Wu A. (2003): Urine Adulteration and Substitution Prior to Drugs of Abuse Testing. Journal of Clinical Ligand Assay.26:11-18.

Wu A., Bristol B.and Sexton K. (1999): Adulteration of urine by Urine Luck. Clin Chem.45:10511057.

Yee D., Atayee R.S., Best B. and Ma J. (2014): Observations on the urine metabolic profile of codeine in pain patients. J. Anal. Toxicol., 38: 86-91. 


\section{هل يمكن ان يمنع غش عينات البول الكثف على الحشيش باستخذام جهاز كروماتوجر افيا الغاز}

$$
\text { رضا محمد السيد' و محمد عواد عبد العاطى' و خالد مسعود محمد' ومها عبد الحميد هلال } 1
$$

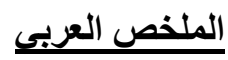

مقدمة: يُعدالحشيش، إلى جانب القهوة والتبغ، أكثر العقاقير ذات التناثثير النفسى استخدامًا في جميع أنحاء العالم، وهو العقار غير القانوني الأكثر شيو عًا، وقد أظهرت الدراسات الحديثة زيادة في انتشار تعاطي الحشيش. ومن اهم المشكلات التى نو اجه اختبار ات الكثف عن المخدرات فى البول هى امكانية غش العينات.

الههف من البحث: دراسة التاثير الكمى والنوعى لخمسة مو اد شائبة على عينات البول الإيجابية للحشيش. طريقة البحث: أجريت هذه الدر اسة التحليلة على عينات بول إيجايبة للحشيش جمعت من المترددين على معمل السموم الاكلينيكية بمستشفيات جامعة سوهاج. نم غش العينات باستخدام الخل، والدرانو، وصابون اليد السائل، وقطرة الفايزين، و الكلور ثم اختبار العينات بواسطة جهاز المقايسة المناعية ثم تأكيدها وتحديد كميتها بو اسطة جهاز كروماتو غر افيا الغاز مقياس الطيف. بطان. النتائج: أظهرت عينات البول المغشوشة بالخل وصابون البد السائل و الدرانو والكلوروقطرة الفايزين نتائج سلبية كاذبة للحشيش عن طريق اختبار المقايسة المناعية كما أظهرت تأكيد الاختبار بواسطة جهاز كروماتو غر افيا الغاز مقياس الطيف أن إضافة الخل و الكلور و الفايزين والدرانو وصابون اليد السائل يقلل تركيز الحشيش بشكل ملحوظ مع زيادة التركيز. الخلاصة: بعض المو اد الغاشة تؤدى الى نتائج سلبية خاطئة في اختبار ات المقايسة المناعية للحشيش، كما ان تاكيد النتائج بواسطة

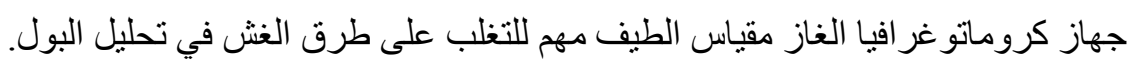

